\title{
Phycoremediation Potential of Botryococcus braunii: Bioremediation and Toxicity of As(III) and As(V)
}

\author{
M. S. Podder ${ }^{1}$ C. B. Majumder ${ }^{1}$
}

Received: 11 January 2016 /Revised: 26 March 2016 / Accepted: 27 March 2016/Published online: 12 May 2016

(C) Springer Science+Business Media Singapore 2016

\begin{abstract}
Worldwide threats of climate change because of greenhouse gas emissions and fuel shortages in near future are posing considerate challenges and therefore it is vital for exploring viable ways of preventing the consequences. The dual usage of microalgae for phycoremediation and biomass production for ecological biofuels production is a practicable choice. Accumulation and toxicity of inorganic arsenic forms $(\mathrm{As}(\mathrm{III})$ and $\mathrm{As}(\mathrm{V}))$ to the green microalgae Botryococcus braunii depends on various environmental factors. This study examined the possibility of using living algae B. braunii for phycoremediation of arsenic-enriched media (As(III) and $\mathrm{As}(\mathrm{V}))$. As(V) was more harmful than $\mathrm{As}(\mathrm{III})$, particularly at $\mathrm{pH}$ 7.0, but it was reverse at $\mathrm{pH}$ 9.0. The phycoremediation efficiency of $\mathrm{As}(\mathrm{V})$ at $\mathrm{pH} 9.0$ by algal cells was higher than that As(III). An increase in concentration of phosphate in growth medium reduced the toxicity and phycoremediation of $\mathrm{As}(\mathrm{III})$ and $\mathrm{As}(\mathrm{V})$. Value of $\mu_{\max }$ remained almost constant after addition of arsenic (either $\mathrm{As}(\mathrm{III})$ or $\mathrm{As}(\mathrm{V})$ ) in the media containing various concentration of phosphate ions, but the value of $K_{s}$ increased. The microalgae $B$. braunii can be employed for tertiary treatment of wastewater and the producing biomass can be utilized as source of renewable energy.
\end{abstract}

Electronic supplementary material The online version of this article (doi:10.1007/s41101-016-0003-1) contains supplementary material, which is available to authorized users.

M. S. Podder

mou.chem11@gmail.com

C. B. Majumder

cbmajumder@gmail.com

1 Department of Chemical Engineering, Indian Institute of Technology, Roorkee, Roorkee 247667, India
Keywords Arsenic - Wastewater - Botryococcus braunii . Phycoremediation · Growth · Monod model

\section{Introduction}

Arsenic is the 20th most abundant element in the Earth's crust, 14th in seawater and 12th in the human body [1] and can be found in water because of natural processes such as weathering reactions, volcanic eruption, and biological activity [2] and also because of anthropogenic activities such as uses of fertilizers and pesticides, mining and smelting operations, and fossil fuel combustion [2-4]. Copper smelting creates a huge volume of wastewater containing large amounts of inorganic compounds, such as heavy metals like lead, copper, zinc, iron, cadmium, bismuth, etc. and highly carcinogenic metalloid-like arsenic species, poses a serious threat toward man and the flora and fauna of our ecosystem contaminating the natural water tables (ground water and surface water) in the vicinity. In copper smelting, wastewater concentration of arsenic is as high as $1979 \mathrm{mg} / \mathrm{L}$ [5]. With the aim of maintaining a good quality of fresh water resources, this wastewater must be treated so that the water can be reverted to the ecosystems. In natural waters, the inorganic form of arsenic mostly exists in trivalent $(\mathrm{As}(\mathrm{III}))$ and pentavalent $(\mathrm{As}(\mathrm{V}))$ oxidation states [6]. Short-term exposure to arsenic may lead to neuropathy, hyperkeratosis, and hypertension and prolonged exposure to higher doses may lead to lung, skin, and liver cancer and may be ultimately death [7]. On the basis of investigation of the fatal effect of arsenic on human body, the maximum contaminant level (MCL) of arsenic in drinking water has been revised from 50 to $10 \mu \mathrm{g} / \mathrm{L}$ by the World Health Organization (WHO) in 1993 [8] and the European Commission in 2003 [9]. Generally, both physical and chemical methods are costly. Moreover, most chemical methods 
raise the conductivity, $\mathrm{pH}$, and total contents of dissolved matter in the wastewater and are not only eco-friendly, but also inexpensive [10]. In this respect, biological or biotreatment of wastewater is a better choice [11]. The use of microorganism for biosorption of arsenic ions from water is an enormously effective process, due to which it is becoming widespread day by day [12-14].

Phycoremediation is the use of macroalgae, microalgae and cyanobacteria for the elimination or biotransformation of contaminants, containing nutrients, heavy metals, and xenobiotics from wastewater and $\mathrm{CO}_{2}$ from waste air (for environmental cleanup) [15]. Phycoremediation is a non-conventional wastewater treatment technology which is achieving attention because of its various benefits including it is non-invasive, costeffective, and environmentally sound alternative to the currently existing physicochemical contaminant remediation methods [16]. The algae have various features which make them perfect contenders for the selective removal of heavy metals, which contain large surface area/volume ratios, high tolerance to heavy metals, ability to grow both heterotrophically and autotrophically, possible for genetic manipulation, phototaxy, and phytochelatin expression [17]. Ting et al. [18] described that the uptake of metal ions by microorganisms in batch systems occurs in two stages; an initial fast uptake (passive uptake) followed by a much slower one (active uptake). In the course of the passive uptake, the metal ions adsorb on the cell surfaces within a relatively few seconds or minutes. In the second uptake stage, the metal ions are transported across the cell membrane and into the cytoplasm. They also developed a mathematical description of these two processes.

Since microalgae uses $\mathrm{CO}_{2}$ as a carbon source, they can grow photoautotrophically without the adding an organic carbon source [19]. The cultivation of algae in wastewater offers the combined advantages of mitigation of greenhouse gases, treatment of the wastewaters, and simultaneously producing algal biomass [20].

A significant concern related to the application of phycoremediation is handling and discarding of the obtained metal-enriched microalgal biomass wastes. At present, this is the bottle neck of the valorisation (breakthrough) of the obtained biomass/applied technique. Waste volume can be reduced by thermal, microbial, physical or chemical means This biomass can be exploited for multiple uses as bioenergy resources (biogas and biofuels), biofertilizer, bio-ore for precious heavy metals, and other valuable chemicals [21, 22].

Hossain and Anantharaman [23] studied the ability of Bacillus subtilis to remove As(III) from aqueous solution. Giri et al. [12, 14] reported the unexploited sorption properties of the Bacillus cereus for the removal of As(III) from aqueous solutions. Teclu et al. [24] and Vaxevanidou et al. [25] also studied the removal of arsenic using the microbial route. Recently, studies related to bioremediation of arsenic from aqueous solution by Inonotus hispidus [26], Ulothrix cylindricum [27], Acidithiobacillus ferrooxidans BY-3 [28], Staphylococcus xylosus [29], Xanthoria parietina [30], Mangeotia genuflexa [13], Rhodococcus sp.WB-12 [31], and Arthrobacter sp. [32] were carried out.

Botryococcus braunii is an autotrophic green colonial microalgae widespread in freshwater of tropical and temperate areas, occasionally in brackish lakes, reservoirs, ponds, and sea [33, 34]. B. braunii was used to remove As(III) (as well as $\mathrm{Cd}^{2+}, \mathrm{Cr}^{6+}$, and $\left.\mathrm{Pb}^{2+}\right)$ from aqueous solution, but the arsenic elimination by this strain is not so far extensively verified [33]. Dayananda et al. [34] studied the growth of B. braunii in shake flasks by using different autotrophic media and found BG11 was the best medium for biomass and hydrocarbon production. So, in the present study the potential of microalgae $B$. braunii was investigated in autotrophic BG11 media.

Although a number of pioneering works have been reported on treatment of arsenic-containing wastewater by various techniques, only a few studies on a microbial route for detoxification of arsenic has been reported so far. The main objective of the present study was to investigate the potential of microalgae $B$. braunii for low-cost and eco-friendly wastewater treatment so as to implement in the management of municipal and industrial wastewater. Specific research goals included: (1) to perform the thorough kinetic study of living microalgae $B$. braunii by culturing in simulated solutions of arsenic (either $\mathrm{As}(\mathrm{III})$ or $\mathrm{As}(\mathrm{V}))$ in terms of dry biomass and chlorophyll content; (2) to optimize the growth rate and phycoremediation potential of the microalgal strain systematically under different experimental conditions, such as initial $\mathrm{pH}$, inoculum size, contact time and initial concentration of arsenic (either $\mathrm{As}(\mathrm{III})$ or $\mathrm{As}(\mathrm{V})$ ) ions; (3) to perform SEMEDX and FTIR studies to analyze surface texture, morphology and element distribution of the biomass; and (4) to determine the effect of phosphate on toxicity and phycoremediation of arsenic (either $\mathrm{As}(\mathrm{III})$ or $\mathrm{As}(\mathrm{V})$ ). Furthermore, the growth of the microalgae in arsenic-enriched media containing various levels of phosphate ions were modeled using the classical Monod equation to identify the effect of phosphate on the toxic nature of arsenic (either $\mathrm{As}(\mathrm{III})$ or $\mathrm{As}(\mathrm{V})$ ) ions to microalgae $B$. braunii in terms of growth inhibition.

\section{Materials and Methods}

\section{Materials}

All the chemicals and reagents were of analytical reagent grade and used without additional purification. Standards, matrix modifier, and wash solutions were prepared with deionized double distilled water. All required chemicals utilized in the experiments were bought from Himedia Laboratories Pvt. Ltd., Mumbai, India. Glassware utilized for purposes of 
experiments was washed in $10 \% \mathrm{HNO}_{3}$ and rinsed with double distilled water.

\section{Microalgae and Culture Medium}

The pure strain of green microalgae B. braunii was collected from Department of Biotechnology, IIT, Roorkee. The compositions of the BG11 medium are given in Tables 1 and 2 as follows:

\section{Stock Culture Maintenance}

The pure culture of green microalgae $B$. braunii was transferred into separate acid-washed $\left(1 \% \mathrm{HNO}_{3}\right)$ Erlenmeyer flasks containing $100 \mathrm{~mL}$ of fresh, sterilized (at $121^{\circ} \mathrm{C}$ temperature, 15 psi pressure for at least $15 \mathrm{~min}$ ) grown in BG11 medium photoautotrophically [34]. Cultures were maintained at $28^{\circ} \mathrm{C}$ in a thermostatically controlled environmental chamber at approximately 2000 lux (Philips $40 \mathrm{~W}$, cool daylight, $6500 \mathrm{~K}$ ) on a $12: 12 \mathrm{~h}$ light/dark cycle. To maintain the exponential growth, $1 \mathrm{~mL}$ of stock culture was aseptically transferred to fresh, sterile BG11 nutrient media every 7 days. To investigate the contamination of stock cultures, agar plates $(12.0 \mathrm{~g} / \mathrm{L})$ were swiped with the culture medium under sterile conditions. Stock cultures were examined in triplicate and control plates were utilized to decide if any contamination was because of plating preparation. Petri plates were stored in an incubator under the same environmental conditions as the stock culture. Plates were observed for the presence of microalgal growth after 1 week.

\section{Preparation of Arsenic-Enriched Water}

Arsenic stock solution was prepared by dissolving salts of $\mathrm{NaAsO}_{2}$ and $\mathrm{Na}_{2} \mathrm{HAsO}_{4}, 7 \mathrm{H}_{2} \mathrm{O}$ (analytical reagent grade) purchased from Himedia Laboratories Pvt. Ltd., Mumbai, India, in double distilled water. BG11 media composition was also added into the solution. Then the prepared growth media was subjected to autoclave sterilization at 15 psi pressure and at

Table 1 Major elements

\begin{tabular}{ll}
\hline Composition & Quantity (per liter) \\
\hline $\mathrm{NaNO}_{3}$ & $1.5 \mathrm{~g}$ \\
$\mathrm{~K}_{2} \mathrm{HPO}_{4}$ & $0.04 \mathrm{~g}$ \\
$\mathrm{MgSO}_{4} \cdot 7 \mathrm{H}_{2} \mathrm{O}$ & 0.075 \\
$\mathrm{CaCl}_{2} \cdot 2 \mathrm{H}_{2} \mathrm{O}$ & 0.036 \\
$\mathrm{Citric} \mathrm{acid}_{\mathrm{Na}} \mathrm{EDTA}$ & $0.006 \mathrm{~g}$ \\
$\mathrm{Na}_{2} \mathrm{CO}$ & \\
Ferric ammonium citrate & $0.001 \mathrm{~g}$ \\
Trace metal mix A5 & $0.02 \mathrm{~g}$ \\
\hline
\end{tabular}

Table 2 Trace metal mix A5

\begin{tabular}{ll}
\hline Composition & Quantity $(\text { per } 100 \mathrm{~mL})^{\mathrm{a}}$ \\
\hline $\mathrm{H}_{3} \mathrm{BO}_{3}$ & $2.86 \mathrm{mg}$ \\
$\mathrm{MnCl}_{2} \cdot 4 \mathrm{H}_{2} \mathrm{O}$ & $1.81 \mathrm{mg}$ \\
$\mathrm{ZnSO}_{4} \cdot 7 \mathrm{H}_{2} \mathrm{O}$ & $0.22 \mathrm{mg}$ \\
$\mathrm{Na}_{2} \mathrm{MoO}_{4} \cdot 2 \mathrm{H}_{2} \mathrm{O}$ & $0.39 \mathrm{mg}$ \\
$\mathrm{CuSO}_{4} \cdot 5 \mathrm{H}_{2} \mathrm{O}$ & $0.08 \mathrm{~g}$ \\
$\mathrm{Co}\left(\mathrm{NO}_{3}\right)_{2} \cdot 6 \mathrm{H}_{2} \mathrm{O}$ & $0.05 \mathrm{~g}$ \\
\hline
\end{tabular}

${ }^{\text {a }}$ Only $1 \mathrm{ml}$ from Trace metal mix A5 was added into the culture solution of major elements

$121{ }^{\circ} \mathrm{C}$ for $15 \mathrm{~min}$. The $\mathrm{pH}$ of the phycoremediation medium was adjusted to the requisite value by dropwise addition of sterile $1 \mathrm{~N} \mathrm{HCl}$ and $1 \mathrm{~N} \mathrm{NaOH}$ solution.

\section{Phycoremediation Experiments}

The factors influencing the growth and phycoremediation efficiency of living microalgae $B$. braunii was investigated in $250 \mathrm{~mL}$ round bottom flask with $100 \mathrm{~mL}$ phycoremediation medium. BG11 medium was served as control. The $\mathrm{pH}$ of the medium was adjusted by dropwise addition of sterile $1 \mathrm{~N} \mathrm{HCl}$ and $1 \mathrm{~N} \mathrm{NaOH}$. An optimum aliquot (10\%, volume of inoculum/volume of growth medium) of preculture was harvested aseptically during the exponential growth phase (OD value $\sim 0.515$ at $680 \mathrm{~nm}$ ), and it was transferred to the fresh media (100 mL) supplemented with arsenic (either As(III) or $\mathrm{As}(\mathrm{V})$ ) of requisite quantity for different studies and the cultures were grown in an environmental chamber for 16 days. Thermostatically controlled environmental chamber was sustained at $28{ }^{\circ} \mathrm{C}$ temperature. Illumination was supplied by continuous cool white fluorescent lamps at 2000 lux (Philips $40 \mathrm{~W}$, cool daylight, $6500 \mathrm{~K}$ ) with a dark/light period of $12: 12 \mathrm{~h}$. In preliminary control experiments, microalgae cultured 3 weeks under experimental conditions exhibited normal growth without distinguishable morphological changes and maximum growth of microalgae was found at 7 days and then the rate of increase in growth was not so insignificant. So, the experimental culture period of 7 days used in all experiments possibly had no negative effects.

Phycoremediation studies were performed in the batch reactors to determine the effect of initial $\mathrm{pH}$, inoculum size, contact time, and initial arsenic (As(III)/As(V)) concentration on the growth of microalgae and the phycoremediation $\%$ of arsenic $(\mathrm{As}(\mathrm{III}) / \mathrm{As}(\mathrm{V}))$ with the range of operating parameters as mentioned in Table 3 (growth study) and Table 4 (phycoremediation study), respectively. The cultures were aerated with $2 \% \mathrm{CO}_{2}$ in air at a flow rate of approximately $150 \mathrm{~mL} / \mathrm{min}$ twice in a day for 30 min by bubbling through the growth medium using an air pump. Aeration of cultures with $\mathrm{CO}_{2}$-enriched air is necessary to achieve high productivities for phototrophic microalgae and also 
Table 3 Different process conditions used for the growth of microalgae

\begin{tabular}{|c|c|c|c|c|c|}
\hline \multirow[t]{2}{*}{ Type of experiments } & \multicolumn{5}{|c|}{ Range of operating parameters } \\
\hline & $\mathrm{pH}$ & $\begin{array}{l}\text { Inoculum size } \\
(\%, v / v)\end{array}$ & $\begin{array}{l}\text { Contact time } \\
\text { (day) }\end{array}$ & $\begin{array}{l}\text { Temp. } \\
\left({ }^{\circ} \mathrm{C}\right)\end{array}$ & $\begin{array}{l}\text { Initial conc. of } \\
\mathrm{As}(\mathrm{III}) \text { or } \mathrm{As}(\mathrm{V}) \\
(\mathrm{mg} / \mathrm{L})\end{array}$ \\
\hline Effect of $\mathrm{pH}$ & $2.0-12.0$ & 10 & 7 & 28 & 50 \\
\hline Effect of inoculum size & $9.0(\mathrm{As}(\mathrm{III})) 9.0(\mathrm{As}(\mathrm{V}))$ & $2-20$ & 7 & 28 & 50 \\
\hline Effect of contact time & $9.0(\mathrm{As}(\mathrm{III})) 9.0(\mathrm{As}(\mathrm{V}))$ & 10 & $1-16$ & 28 & 50 \\
\hline Effect of initial arsenic conc. & $9.0(\mathrm{As}(\mathrm{III})) 9.0(\mathrm{As}(\mathrm{V}))$ & 10 & 7 & 28 & $50-10,000$ \\
\hline
\end{tabular}

In case of effect of $\mathrm{pH}, \mathrm{pH}$ was varied from 2 to 12 and all other parameters are kept constant. So it was shown in italics. Other are simple.

Similarly, in case of effect of inoculum size, inoculum size was varied from 2 to 20 and all other parameters are kept constant. So it was shown in italics. Other are normal.

Similarly, in case of effect of contact time, contact time was varied from 1 to 16 day and all other parameters are kept constant. So it was shown in italics. Other are normal.

Similarly, in case of effect of initial arsenic conc., arsenic conc. was varied from 50 to $10000 \mathrm{mg} / \mathrm{L}$ and all other parameters are kept constant. So it was shown in italics. Other are normal.

Basically to highlight the parameter which is varying, it is written in italics.

helps in mixing and $\mathrm{pH}$ buffering [35]. Then the cultures were agitated for another $20 \mathrm{~min}$ to prevent algal cells sedimentation on the flasks bottom and to enhance the distribution of $\mathrm{CO}_{2}$ in the growth medium [36].

Samples $(5 \mathrm{~mL})$ were withdrawn at certain time intervals and then centrifuged (Remi Instruments Ltd., Mumbai India) at $5000 \times \mathrm{g}$ for $5 \mathrm{~min}$, and the supernatant fraction was analyzed for residual concentration of arsenic (either As(III) or As $(V))$ ions in the medium using ThermoFisher Scientific iCE 3000 Series AA graphite furnace atomic absorption (GFAA) spectrometer (The detail procedure of residual arsenic concentration measurement is provided with supplementary materials). Cell growth was determined by measuring an optical density (OD) of the samples collected intermittently from the flask was at $680 \mathrm{~nm}$. A correlation for converting OD680 values to microalgal dry weight was established from the calibration curve (The detail procedure of bacterial cell growth measurement is provided with Electronic Supplementary Materials). Microalgal mass was also analyzed in terms of chlorophyll content (The detail procedure of chlorophyll measurement is provided with Electronic Supplementary Materials). Arithmetic mean of results of two similar experiments was used to estimate data.

The phycoremediation $\%$ of metal ion is evaluated utilizing the following equation:

Phycoremediation $\%=\frac{\left(C_{0}-C_{f}\right)}{C_{0}} \times 100$

\section{Characterization}

The 7-day culture, grown in BG11 media in the absence and presence of $2000 \mathrm{mg} / \mathrm{L}$ arsenic (As(III)/As(V)) ions, was centrifuged at $5000 \times \mathrm{g}$ for $5 \mathrm{~min}$. The supernatant was discarded, and the cells were washed two times with phosphate buffer solution. The washed cells were resuspended in glutaraldehyde $(2 \%, v / v)$ for $2 \mathrm{~h}$. The resuspended cells were centrifuged at $5000 \times g$ for $5 \mathrm{~min}$. The supernatant was discarded and the cells were treated with serial dilution of ethanol. The samples were

Table 4 Different process conditions used for phycoremediation of $\mathrm{As}(\mathrm{III})$ and $\mathrm{As}(\mathrm{V})$ by microalgae

\begin{tabular}{|c|c|c|c|c|c|}
\hline \multirow[t]{2}{*}{ Type of experiments } & \multicolumn{5}{|c|}{ Range of operating parameters } \\
\hline & $\mathrm{pH}$ & $\begin{array}{l}\text { Inoculum size } \\
(\% \mathrm{v} / \mathrm{v})\end{array}$ & $\begin{array}{l}\text { Contact time } \\
\text { (h) }\end{array}$ & $\begin{array}{l}\text { Temp. } \\
\left({ }^{\circ} \mathrm{C}\right)\end{array}$ & $\begin{array}{l}\text { Initial conc. of } A s(\mathrm{III}) \\
\text { or } \mathrm{As}(\mathrm{V})(\mathrm{mg} / \mathrm{L})\end{array}$ \\
\hline Effect of $\mathrm{pH}$ & $2.0-12.0$ & 10 & 144 & 28 & 50 \\
\hline Effect of inoculum size & $9.0(\mathrm{As}(\mathrm{III})) 9.0(\mathrm{As}(\mathrm{V}))$ & $2-20$ & 144 & 28 & 50 \\
\hline Effect of contact time & $9.0(\mathrm{As}(\mathrm{III})) 9.0(\mathrm{As}(\mathrm{V}))$ & 10 & $4-360$ & 28 & 50 \\
\hline Effect of initial arsenic conc. & $9.0(\mathrm{As}(\mathrm{III})) 9.0(\mathrm{As}(\mathrm{V}))$ & 10 & 144 & 28 & $50-2000$ \\
\hline
\end{tabular}

To highlight the parameter which is varying, it is written in italics. 
serially diluted to $30,50,70,90$, and finally $100 \%$. Every dilution of ethanol was applied on the cells for 10 min individually. The cells were allowed to evaporate ethanol under atmospheric conditions. The cells were subjected to gold sputtering using Sputter Coater, Edwards S150, which provides conductivity to the samples, under vacuum followed by degassing. Finally, the cells were characterized by scanning electron microscopy (Fe-SEM) and EDX. The measurements of SEM were done for observing the surface morphologies of the microalgae (SEM; LEO Electron Microscopy, England) [37]. The images were taken with an accelerator voltage $=15 \mathrm{kV}$ and an emission current $=100 \mu \mathrm{A}$ by the Tungsten filament.

The microalgal cells grown in BG11 media were centrifuged at $5000 \times g$ for $5 \mathrm{~min}$. The cells obtained after centrifugation were washed twice with phosphate buffer solution and dried in oven at $353 \mathrm{~K}$ for $24 \mathrm{~h}$. The dried biomass was finally grounded in mortar to obtain fine powder. The finely powdered cell biomass was mixed with photometric potassium bromide $(\mathrm{KBr})$ to make a pellet of $1 \%(w / w)$. The pellet was subjected to Fourier transform infrared spectrometer (NICHOLET 6700, coupled with OMNIC software version 6.2) spectrum between wave number $4000-400 \mathrm{~cm}^{-1}$ [37]. The infrared spectra of the unloaded and metal loaded B. braunii biomass were obtained using FTIR.

\section{Modeling of Growth Kinetics and Determination of Kinetic Parameters for Growth of Algal Biomass in Pure and Arsenic Containing Media}

The classical Monod equation was recommended for modeling the growth kinetics of the current microalgae $B$. braunii as follows [20]:

$$
\mu=\frac{\mu_{\max } C_{A}}{\left(K_{S}+C_{A}\right)}
$$

\section{Results and Discussion}

\section{Effect of Initial pH on Growth Properties of B. braunii}

One of the most significant factors in microalgal cultivation is $\mathrm{pH}$ because it controls the solubility and availability of $\mathrm{CO}_{2}$ and essential nutrients and since it can have an important influence on algal metabolism [38]. Since the $\mathrm{pH}$ plays a major role in the growth of the microalgae $B$. braunii, so effect of initial $\mathrm{pH}$ on biomass concentration of the microalgae was explored in the $\mathrm{pH}$ range of 1.0-12.0 in the absence and presence of $50 \mathrm{mg} / \mathrm{L}$ of arsenic ions (either $\mathrm{As}(\mathrm{III})$ or $\mathrm{As}(\mathrm{V})$ ).

The microalgae could not grow at extreme low $\mathrm{pH} 1.0$ and also at extreme high $\mathrm{pH} 12.0$ in the absence and presence of both $\mathrm{As}(\mathrm{III})$ and $\mathrm{As}(\mathrm{V})$ (Fig. 1) [39]. The highest biomass

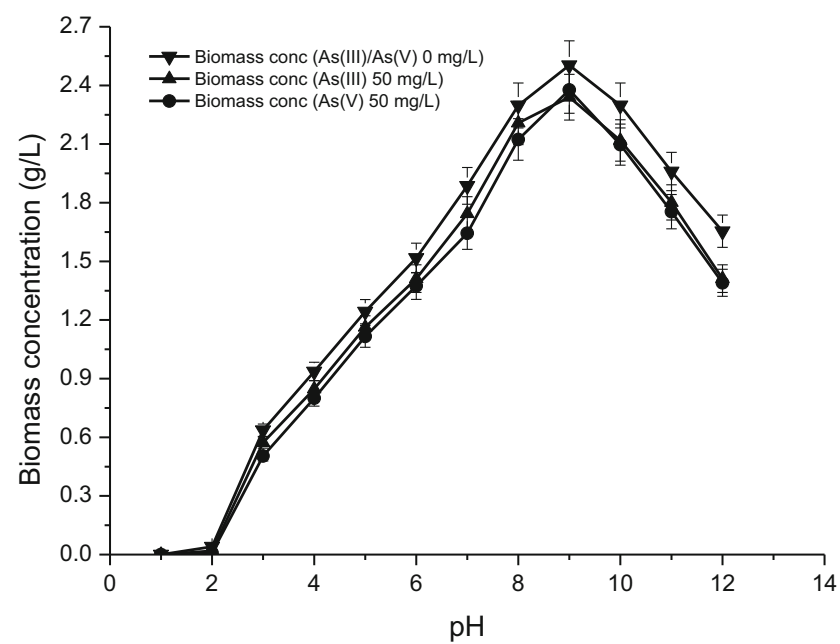

Fig. 1 Effect of $\mathrm{pH}$ on growth of $B$. braunii in absence and presence of $\mathrm{As}(\mathrm{III})$ and $\mathrm{As}(\mathrm{V})$ (inoculum size $(\%, v / v), 10$; incubation time, 7 days; initial arsenic concentration, $50 \mathrm{mg} / \mathrm{L}$; temperature, $28{ }^{\circ} \mathrm{C}$; dark/light period, 12:12 h). (Error bars represent means \pm standard errors from the mean of duplicate experiments)

concentration achieved at $\mathrm{pH} 9.0$ in the absence of arsenic ions was found to be $2.503 \mathrm{~g} / \mathrm{L}$, respectively. The highest biomass concentration was also determined at $\mathrm{pH} 9.0$ as 2.34 and $2.377 \mathrm{~g} / \mathrm{L}$, respectively, in the media containing $50 \mathrm{mg} / \mathrm{L} \mathrm{As}(\mathrm{III})$ and $\mathrm{As}(\mathrm{V})$ ions, respectively.

Microalgae assimilate inorganic carbon in the photosynthesis. The inorganic carbon species normally used by microalgae are $\mathrm{CO}_{2}$. The amount of $\mathrm{CO}_{2}$ dissolved in water varies greatly with $\mathrm{pH}$ and addition of $\mathrm{CO}_{2}$ results in a $\mathrm{pH}$ decrease [40]. The $\mathrm{pH}$ can increase significantly in microalgal cultures owing to the uptake of inorganic carbon by microalgae [38]. Remarkably, $\mathrm{pH}$ is the main influential factor of relative concentrations of the carbonaceous species in water [41]. The availability of carbon from $\mathrm{CO}_{2}$ will be limited at higher $\mathrm{pH}$, which successively inhibits the growth of microalgae [41]. The carbon for microalgae is available in form of carbonates at higher $\mathrm{pH}$ [42]. Higher $\mathrm{pH}$ also reduces the affinity of microalgae to free $\mathrm{CO}_{2}$ [41]. The flexibility of the cell wall of mother cells increases at higher $\mathrm{pH}$ preventing its rupture and inhibiting the release of autospore, so the time for cell cycle completion increases [43]. At higher $\mathrm{pH}$ values, such as at $\mathrm{pH}$ greater than 9.0, most of the inorganic carbon is in form of carbonate $\left(\mathrm{CO}_{3}{ }^{2-}\right)$ which cannot be assimilated by the algae acidic conditions can change nutrient uptake similar to alkaline $\mathrm{pH}$ [44]. So, the highest growth of microalgae was found to be at 9.0.

Biomass concentration of microalgae was found to be less in the presence of arsenic (either $\mathrm{As}(\mathrm{III})$ or $\mathrm{As}(\mathrm{V})$ ) ions compared with control owing to suppression of the growth of microalgae. In batch cultures, the cells grow exponentially until restricted by a nutrient or some other growth factor or until an inhibitor accumulates sufficiently to stop further algal growth [45]. In the current investigation, it was agreed that 
inorganic arsenic (either $\mathrm{As}(\mathrm{III})$ and $\mathrm{As}(\mathrm{V}))$ ion was toxic to algal cells; so the growth decreased with an increase in arsenic concentration in the culture medium.

The availability and toxicity of inorganic arsenic to B. braunii depend on the arsenic concentration, its chemical valence, and environmental factors as $\mathrm{pH}$ during the exposure. However, the biouptake and toxicity of inorganic arsenic species remains controversial. Although As(III) was considered to be more toxic than $\mathrm{As}(\mathrm{V})$ in animals and marine phytoplankton, their toxicity was reversed in freshwater microalgae $[46,47]$. However, many exceptions to this rule were also reported. $\mathrm{As}(\mathrm{V})$ and $\mathrm{As}(\mathrm{III})$ exerts equal toxicity to freshwater algae Stichococcus bacillaris at pH 8.2 with phosphate levels between 0.03 and $0.3 \mathrm{mg} \mathrm{P} / \mathrm{L}$ [48]. Lower $\mathrm{pH}$ increased $\mathrm{As}(\mathrm{V})$ toxicity to $S$. bacillaris [48]. They reported that induced thiolpeptides-short-chain phytochelatins $\left(\mathrm{PC}_{2-3}\right)$ are produced in response to arsenic exposure. $\mathrm{As}(\mathrm{V})$ was more toxic than $\mathrm{As}(\mathrm{III})$, especially at the near neutral $\mathrm{pH}$ 6.8.than at $\mathrm{pH} 8.2$ because more phytochelatins $\left(\mathrm{PC}_{2-3}\right)$ were produced in response to $\mathrm{As}(\mathrm{V})$ and $\mathrm{As}(\mathrm{III})$ under exposure conditions. However, the intracellular arsenic concentration was higher than the concentration of phytochelatins able to detoxify the metal under the identical conditions. Equal toxicity of As(III) and $\mathrm{As}(\mathrm{V})$ was also found from the $72 \mathrm{~h}$ growth inhibition tests for the freshwater algal specie Chlorella (pH 7.6) [46], whereas $\mathrm{As}(\mathrm{V})$ was more toxic than As(III) for Monoraphidium arcuatum (pH 7.6). Karadjova et al. [47] also demonstrated that inorganic arsenic species (As(III) and As $(\mathrm{V}))$ exhibit equal toxicity toward C. salina in seawater (pH 8.1).

The optimum $\mathrm{pH}$ for the growth evaluated in the present investigation is in agreement with the optimum $\mathrm{pH}$ for the growth of cyanobacterial strain reported by Kushwaha et al. [20]. They reported that the cyanobacterial growth is very sensitive to $\mathrm{pH}$ and the optimal $\mathrm{pH}$ for the growth of cyanobacterial consortium of Oscillatoria subbrevis and Gloeocapsa atrata was 9.0 in the $\mathrm{Chu}-10$ growth media. Generally, the higher toxicity of $\mathrm{As}(\mathrm{V})$ than $\mathrm{As}(\mathrm{III})$ toxicity to $S$. bacillaris is in agreement with reports of toxicity of arsenic toward natural algal communities in fresh and marine waters [49].

\section{Effect of Initial pH on Phycoremediation Properties of $\boldsymbol{B}$. braunii}

The $\mathrm{pH}$ is one of the significant factors that considerably influences the adsorbate ion speciation, the chemistry of solution, interaction between adsorbate and biosorbent, and surface charge of biosorbent surface [50]. In the current study, the effect of $\mathrm{pH}$ on phycoremediation of both $\mathrm{As}(\mathrm{III})$ and $\mathrm{As}(\mathrm{V})$ ions were performed in range of 2.0-12.0 and the results are shown in Fig. 2. In the present study, the term phycoremediation is used to describe any of these possible modes of interactions

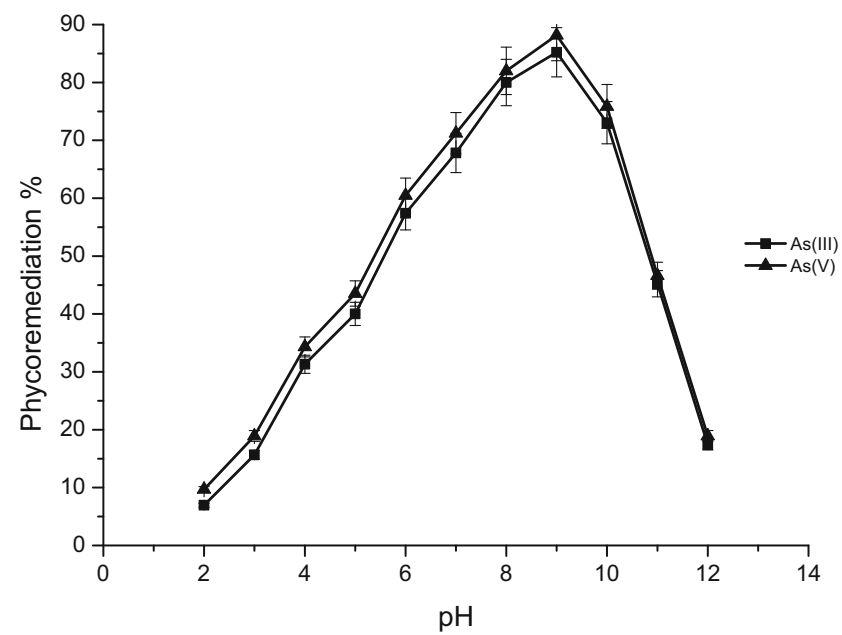

Fig. 2 Effect of initial $\mathrm{pH}$ on phycoremediation of $\mathrm{As}(\mathrm{III})$ and $\mathrm{As}(\mathrm{V})$ by B. braunii (inoculum size $(\%, v / v), 10$; contact time, $144 \mathrm{~h}$; initial arsenic concentration, $50 \mathrm{mg} / \mathrm{L}$; temperature, $28{ }^{\circ} \mathrm{C}$ ). (Error bars represent means \pm standard errors from the mean of duplicate experiments)

(passive uptake, i.e., sorption and active uptake, i.e., accumulation) between the metal ion and the surface of the cells without distinction.

From Fig. 2, it was evident that the phycoremediation $\%$ of both $\mathrm{As}(\mathrm{III})$ and $\mathrm{As}(\mathrm{V})$ were higher in basic media than in acidic media and the highest removal was found at $\mathrm{pH} 9.0$. This may be attributed to the favorable growth of $B$. braunii biomass in alkaline media $\mathrm{pH}$ (i.e., $\mathrm{pH} 9.0$ ).

The phycoremediation of both $\mathrm{As}(\mathrm{III})$ and $\mathrm{As}(\mathrm{V})$ varied significantly depending upon the arsenic species also. The difference in the phycoremediation \% of $\mathrm{As}(\mathrm{III})$ and $\mathrm{As}(\mathrm{V})$ could be elucidated on the basis of the charge on the species of arsenic and the surface charges of the algal biomass.

It was agreed from Fig. 2 that the phycoremediation of both $\mathrm{As}(\mathrm{III})$ and $\mathrm{As}(\mathrm{V})$ ions (15.652 and $18.923 \%$, respectively) were very poor in the $\mathrm{pH}$ range $<3.0$. With the rise in $\mathrm{pH}$ from 3.0 to 9.0 , there was a significant increase in the phycoremediation of both As(III) and As(V) ions. The highest phycoremediation \% of $\mathrm{As}(\mathrm{III})$ and $\mathrm{As}(\mathrm{V})$ ions were achieved as 85.217 and 88.154 , respectively, at $\mathrm{pH}$ 9.0. Then a sharp decrease in the phycoremediation was found and $\mathrm{As}(\mathrm{V})$ exhibited more phycoremediation than As(III). These results can be understood from the following explanations.

In the $\mathrm{pH}$ range of $2.0-9.0$ and $10.0-12.0, \mathrm{As}(\mathrm{III})$ exists generally in neutral $\left(\mathrm{H}_{3} \mathrm{AsO}_{3}\right)$ and anionic $\left(\mathrm{H}_{2} \mathrm{AsO}_{3}{ }^{-}\right)$forms, respectively. Reports also approve that $\mathrm{As}(\mathrm{V})$ exists mostly in the monovalent form of $\mathrm{H}_{2} \mathrm{AsO}_{4}{ }^{-}$in the $\mathrm{pH}$ range 3.0-6.0, yet at $\mathrm{pH}$ near 2.0, a small extent of $\mathrm{H}_{3} \mathrm{AsO}_{4}$ also remains. However a divalent anion $\mathrm{HAsO}_{4}{ }^{2-}$ prevails at higher $\mathrm{pH}$ values (>8.0); both species co-exist in the intermediate region of $\mathrm{pH} 6.0-8.0$ [51]. The dissociation constants of these As(III) and $\mathrm{As}(\mathrm{V})$ are shown in Table 5 [52].

Also at low $\mathrm{pH}$ 1.0-6.0, the density of hydrogen ion was quite high against $\mathrm{As}(\mathrm{III})$ and $\mathrm{As}(\mathrm{V})$ ions, which resulted in 
Table 5 Dissociation constants of arsenic species

\begin{tabular}{llc}
\hline Forms of arsenic species & Dissociation reactions & $\begin{array}{c}\text { Dissociation } \\
\text { constants }\end{array}$ \\
\hline Arsenious acid & $\mathrm{H}_{3} \mathrm{AsO}_{3} \rightarrow \mathrm{H}^{+}+\mathrm{H}_{2} \mathrm{AsO}_{3}{ }^{-}$ & 9.23 \\
& $\mathrm{H}_{2} \mathrm{AsO}_{3}{ }^{-} \rightarrow \mathrm{H}^{+}+\mathrm{HAsO}_{3}{ }^{2}$ & 12.13 \\
& - & \\
& $\mathrm{HAsO}_{3}{ }^{2-} \rightarrow \mathrm{H}^{+}+\mathrm{AsO}_{3}{ }^{3-}$ & 13.40 \\
Arsenic acid & $\mathrm{H}_{3} \mathrm{AsO}_{4} \rightarrow \mathrm{H}^{+}+\mathrm{H}_{2} \mathrm{AsO}_{4}{ }^{-}$ & 2.22 \\
& $\mathrm{H}_{2} \mathrm{AsO}_{4}{ }_{-}^{-} \rightarrow \mathrm{H}^{+}+\mathrm{HAsO}_{4}{ }^{2}$ & 6.98 \\
& $\mathrm{HAsO}_{4}{ }^{2-} \rightarrow \mathrm{H}^{+}+\mathrm{AsO}_{4}{ }^{3-}$ & 11.53 \\
\hline
\end{tabular}

protonation of the components of the cell wall, i.e., the surface of microalgae $B$. braunii biomass. Thus, the amine and hydrox$y$ l group in the surfaces of algal biomass were vastly protonated in acidic conditions. The protonation of algal cell wall moieties reduced the phycoremediation efficiency because there was a strong electrostatic interaction remains between positively charged surface of the biomass and oxyanions [53]. Comte et al. [54] described that the deprotonated form of the reactive sites in cell wall, generally amino, phosphoric, and carboxylic groups, is mainly responsible for the metal ions binding to EPS. Chojnacka et al. [55] also stated that various functional groups of cell wall of microalgal biomass are responsible for binding of metal ions. The solution $\mathrm{pH}$ influences the ionization state of these functional groups. Anions could be anticipated to interact more strongly with cells as the concentration of positive charges rises.

The surfaces of microalgal biomass are vastly protonated in extreme acidic conditions and such a condition is not so encouraging for removal of $\mathrm{As}(\mathrm{III})$ and $\mathrm{As}(\mathrm{V})$ due to the presence of neutral $\mathrm{As}(\mathrm{III})$ and $\mathrm{As}(\mathrm{V})$ species in this range, resulting in virtually less change in the phycoremediation within the $\mathrm{pH}$ range 2.0-4.0. Surface sites are positively charged at lower $\mathrm{pH}$ of the medium and therefore attract negatively charged $\mathrm{As}(\mathrm{III})$ and $\mathrm{As}(\mathrm{V})$ by an electrostatic interaction or columbic force [56, 57]. The surface of $B$. braunii biomass fulfills the coordination shells with the prevailing $\mathrm{OH}$ group with the materials under hydration. On the variation of $\mathrm{pH}$, these surface active $\mathrm{OH}$ groups may further bind or release $\mathrm{H}^{+}$where the surface remains positive because of various reactions provided in the Electronic Supplementary Materials. Though many microorganisms have been revealed to volatilize arsenic, exploring the potential of microbial volatilization or vaporization for bioremediation is still under considerable debate due to their low efficiency. Maximum studies of microbial communities on volatilizing arsenic have concentrated on archaea, bacteria, and fungi with little attention to other eukaryotic microorganisms, such as aquatic alga and protozoans. A few eukaryotic microorganisms have been proved to volatilize arsenic such as a Yellowstone thermoacidophilic eukaryotic alga, Cyanidioschyzon sp., [58], a marine green microalgae
Ostreococcus tauri [59]. Studies exhibited that arsenic volatilization had a direct relationship with microbial growth and nutrient levels [60]. In the experiments on removing arsenic compounds, while organic matter was added, small amounts of innate arsenic present in retorted shale could be volatilized $[61,62]$. In the present study, no such organic matter was added. So $B$. braunii could not vaporize or volatilize arsenic $(\mathrm{As}(\mathrm{III}) / \mathrm{As}(\mathrm{V}))$ rom wastewater.

The degree of protonation of the surface decreases progressively, with the increase in $\mathrm{pH}$ of the system. The highest phycoremediation of $\mathrm{As}(\mathrm{V})$ was found at $\mathrm{pH} 9.0$ where the prevailing species of $\mathrm{As}(\mathrm{III})$ was only non-ionic species $\mathrm{H}_{3} \mathrm{AsO}_{3}$ [2], might be attributed to several products of undetermined reaction during the process of phycoremediation. The neutral $\left(\mathrm{H}_{3} \mathrm{AsO}_{3}\right)$ and monoanionic $\left(\mathrm{H}_{2} \mathrm{AsO}_{3}{ }^{-}\right)$species are thus considered to be responsible for the phycoremediation of As(III), also due to the substitution of hydroxyl ions or water molecules. The neutral species $\left(\mathrm{H}_{3} \mathrm{AsO}_{3}\right)$ cannot undergo electrostatic interaction with the microalgal biomass. However, such species can interact with the unprotonated amino groups $[29,32]$. The dominant species of $\mathrm{As}(\mathrm{V})$ in the above-mentioned $\mathrm{pH}$ range are $\mathrm{H}_{2} \mathrm{AsO}_{4}{ }^{-}$ions, which can be phycoremediated on the microalgal biomass by substituting hydroxyl ions or coordination of hydroxyl groups with the microalgal biomass [32, 53]. At pH 5.0-9.0, anionic species of $\mathrm{As}(\mathrm{V})\left(\mathrm{H}_{2} \mathrm{AsO}_{4}{ }^{-}\right.$and $\left.\mathrm{HAsO}_{4}{ }^{2-}\right)$ exists and the surface of microalgal biomass is also protonated and so a strong electrostatic interaction remains between positively charged microalgal biomass surface and oxyanions and as a result the removal improved in this $\mathrm{pH}$ range because of the increase in $\mathrm{HAsO}_{4}{ }^{2-}$ species with the rise in $\mathrm{pH}$ of the solution. The dominant species of $\mathrm{As}(\mathrm{V})$ in the above-mentioned $\mathrm{pH}$ range are $\mathrm{H}_{2} \mathrm{AsO}_{4}{ }^{-}$ions, which can be phycoremediated on the microalgal biomass by substituting hydroxyl ions or coordination of hydroxyl groups with the microalgal biomass [32, 53]. So, the highest removal of $\mathrm{As}(\mathrm{V})$ was found to be at $\mathrm{pH}$ 9.0.

With the increase in $\mathrm{pH}$ of the system, the degree of protonation of the surface decreased gradually. As the $\mathrm{pH}$ of the solution increased more than 9.0 (alkaline medium), the negatively charged species $\mathrm{H}_{2} \mathrm{AsO}_{3}{ }^{-}$and $\mathrm{H}_{2} \mathrm{AsO}_{4}{ }^{2-}$ started to govern in the medium and cell surface also inclines to gain negative charges $\left(\mathrm{OH}^{-}\right)$resulting in the reduction of phycoremediation of both $\mathrm{As}(\mathrm{III})$ and $\mathrm{As}(\mathrm{V})$ [51]. This process can be defined in three stages: (1) the decline may be because of the negatively charged adsorbate by accumulating hydroxyl ions $\left(\mathrm{OH}^{-}\right)$on the surface of microalgal biomass, (2) may be because of the ionization of very weak acidic functional groups of the microalgal biomass, or both at higher $\mathrm{pH}$ values, and/or (3) a repulsive force may exist between the anionic species and the negatively charged surface of the algal biomass $[12,14,51]$. This results in reduced As(III) and $\mathrm{As}(\mathrm{V})$ removal at higher $\mathrm{pH}$ values [51]. 
More attraction among the $\mathrm{As}(\mathrm{V})$ ions and $\mathrm{H}^{+}$ions on the surface of algal biomass may be the motive for the maximum $\mathrm{As}(\mathrm{V})$ phycoremediation at $\mathrm{pH} 9.0$ compared with As(III).

\section{Effect of Inoculum Size on Growth Properties of B. braunii}

The volume of inoculum utilized for culturing the microalgae can influence the growth of B. braunii [63]. The fixed volume of a culture medium means that it can only contain limited nutrients for the microalgae. Moreover, the consumption of the nutrients mainly depends on the population of microalgae. The microalgal inoculum size should therefore be controlled to ensure a high growth of microalgae in the limited volume of medium [63]. To optimize the inoculum size for the algal growth, the inoculum concentration was in the flasks were varied from 2 to $20 \%(v / v)$ both in the absence and presence of arsenic ions (either As(III) or As(V)) (Fig. 3).

An increase in biomass concentration from 1.111 to $2.308 \mathrm{~g} / \mathrm{L}$ was observed in microalgal growth if the inoculum size was increased from 2 to $8 \%$ in absence of arsenic ions. The maximum biomass concentration $(2.503 \mathrm{~g} / \mathrm{L})$ was found for inoculum size of $10 \%(v / v)$. Drop of biomass concentration from 2.313 to $0.889 \mathrm{~g} / \mathrm{L}$ was found in microalgal growth if the inoculum size was increased from 12 to $20 \%(v / v)$. The maximum biomass concentration was found to be for inoculum size of $10 \%(v / v)$ for both presence of arsenic (either $\mathrm{As}(\mathrm{III})$ or $\mathrm{As}(\mathrm{V}))$ ions also. A higher inoculum of $20 \%(v / v)$ was observed to decrease the algal growth at a higher extent than if the lower inoculum size of $2 \%(v / v)$ was used. So, higher inoculum sizes did not essentially give higher growth of cell. It can be explained by the following explanations.

An improved distribution of dissolve $\mathrm{CO}_{2}$ as well as more efficient nutrient uptake also leads to a higher growth of

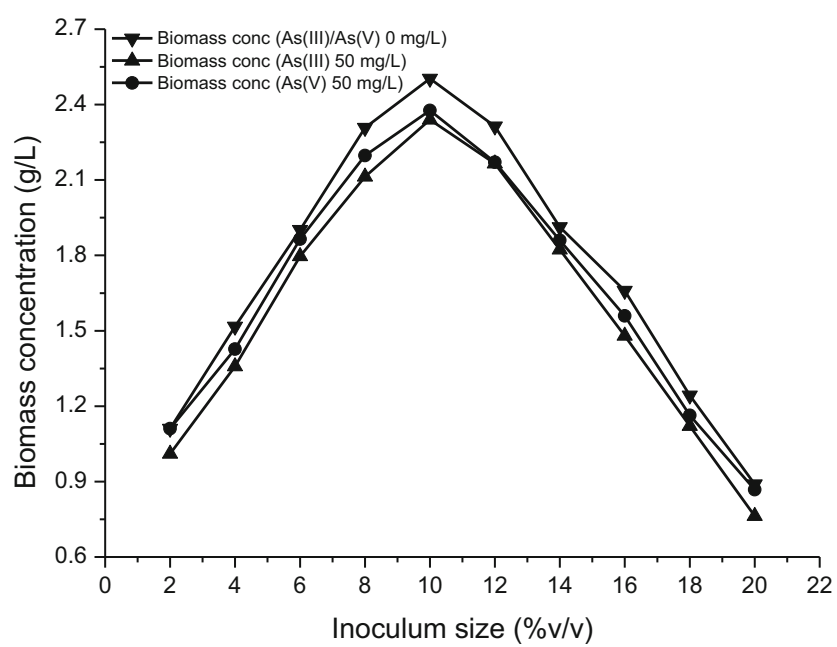

Fig. 3 Effect of inoculum size on growth of $B$. braunii in absence and presence of $\mathrm{As}(\mathrm{III})$ and $\mathrm{As}(\mathrm{V})(\mathrm{pH}, 9.0$; incubation time, 7 days; initial arsenic concentration, $50 \mathrm{mg} / \mathrm{L}$; temperature, $28{ }^{\circ} \mathrm{C}$; dark/light period, $12: 12 \mathrm{~h}$ ). (Error bars represent means \pm standard errors from the mean of duplicate experiments) microalgae [63, 64]. At small inoculum volume microalgae would then to lead to high growth due to the higher surface area to volume ratio and more efficient uptake of nutrient $[63$, $65]$. In the present study, when inoculum size is low $(<10 \%$ $(v / v)$ ), higher growth of microalgae was expected but optical density of cell suspension was found to be low. This may be because of overpopulated culture and fixed amount of nutrient with which the microorganisms begin to liberate proteolytic enzyme enhancing self-consumption [66].

This can also be explained the fact of cell-environment interaction. Two explanations seem possible: (1) that microalgae interact directly with one another for inhibiting the growth: such interaction is termed contact inhibition; and (2) that microalgae interact with the environment in such a way as to reduce it no longer conductive for further growth. Furthermore, if contact inhibition happened, one would not anticipate microalgae to produce large colonies while spreading on a nutrient agar plate. It therefore seems most possible that the event(s) instigating the cessation of growth in a batch culture reside in changes induced in the environment by the growth of the microalgae. It can also be explained by two possibilities: either growth leads to the depletion of some essential nutrient substances from the environment, or else growth leads to the accumulation of products that finally reach toxic concentrations $[67,68]$. If the inoculum sizes are too small $(<4 \%)$, insufficient number of microalgae would lead to a reduced growth of microalgae $[63,64]$.

On the other hand, higher inoculum sizes $(>10 \%(v / v))$ result in the lack of dissolve $\mathrm{CO}_{2}$ and increased competition toward nutrient and depletion of nutrient in the culture media resulting in lower growth of microalgae [63-65]. Highdensity microalgae cultures grown under photoautotrophic method demand a large amount of $\mathrm{CO}_{2}$ while the high concentrations of $\mathrm{O}_{2}$ produced by the photosynthesis process can became an inhibitory condition for the growth of microalgae [69].

Other researchers have stated different optimum inoculum sizes for various bacteria: $5 \%(v / v)$ for B. subtilis strain Rand [63], $3 \%(v / v)$ for Z3-Staphylococcus aureus, KS1Escherichia coli, and KHL2-Pseudomonas aeruginosa [66]. So, different microorganisms require various percentages of inoculum sizes for the highest cell growth. So, in the present study amount of inoculum size were optimized and $10 \%(v / v)$ of inoculum size gave the best result than other size of inoculum.

\section{Effect of Inoculum Size on Phycoremediation Properties of $B$. braunii}

The influence of inoculum size on phycoremediation of $B$. braunii was performed by varying inoculum volume in the range of $2-20 \%(v / v)$ in the growth media in the absence and presence of arsenic (either $\mathrm{As}(\mathrm{III})$ or $\mathrm{As}(\mathrm{V}))$ ions. For two 
arsenic species (As(III) and $\mathrm{As}(\mathrm{V}))$, the phycoremediation \% increased when the inoculum size was varied in the range of 1 to $8 \%(v / v)$ and reached a maximum at inoculum size of $10 \%$ $(v / v)$ for both $\mathrm{As}(\mathrm{III})$ and $\mathrm{As}(\mathrm{V})$ ions. After that, a sharp decline in the phycoremediation \% was observed (Fig. 4).

For $2 \%(v / v)$ inoculum, phycoremediation $\%$ of As(III) and $\mathrm{As}(\mathrm{V})$ was 71.304 and 80.462 , which increased to 85.217 and 88.154 , respectively, at $10 \%(v / v)$ inoculum of $B$. braunii microalgae and then reduced to 60.87 and 77.385 , respectively, at an inoculum size of $20 \%(v / v)$. It is found in the above study that the highest biomass concentration was found for $10 \%(v / v)$ inoculum size. So, maximum phycoremediation of both $\mathrm{As}(\mathrm{III})$ and $\mathrm{As}(\mathrm{V})$ were found at an inoculum size of $10 \%$. Figure 4 also shows that the phycoremediation efficiency of As(III) was greater affected by the inoculum size. It was supported by greater toxicity of $\mathrm{As}(\mathrm{III})$ than that of $\mathrm{As}(\mathrm{V})$ which suppressed the growth of microalgae. The microalgae produced phytochelatins $\left(\mathrm{PC}_{2-3}\right)$ in response to $\mathrm{As}(\mathrm{III})$ and $\mathrm{As}(\mathrm{V})$, but the level of phytochelatins in cells was higher after exposure to $\mathrm{As}(\mathrm{V})$ than to $\mathrm{As}(\mathrm{III})$, signifying higher $\mathrm{As}(\mathrm{V})$ availability and accumulation in algal cells than that of As(III) at the same external concentrations [48].

\section{Effect of Initial Arsenic Concentration on Growth Properties of $B$. braunii}

Microalgal growth curves in the absence and presence of increasing concentrations of arsenic (either $\mathrm{As}(\mathrm{III})$ or $\mathrm{As}(\mathrm{V})$ ) ions $(50,100,500,1000,1500$, and $2000 \mathrm{mg} / \mathrm{L})$ in the BG11 growth media are shown in Fig. 5.

Growth of the microalga $B$. braunii was not inhibited by concentrations of arsenic ions (either $\mathrm{As}(\mathrm{IIII})$ or $\mathrm{As}(\mathrm{V}))$ up to $1000 \mathrm{mg} / \mathrm{L}$, and the lag phase was approximately 1 day and the

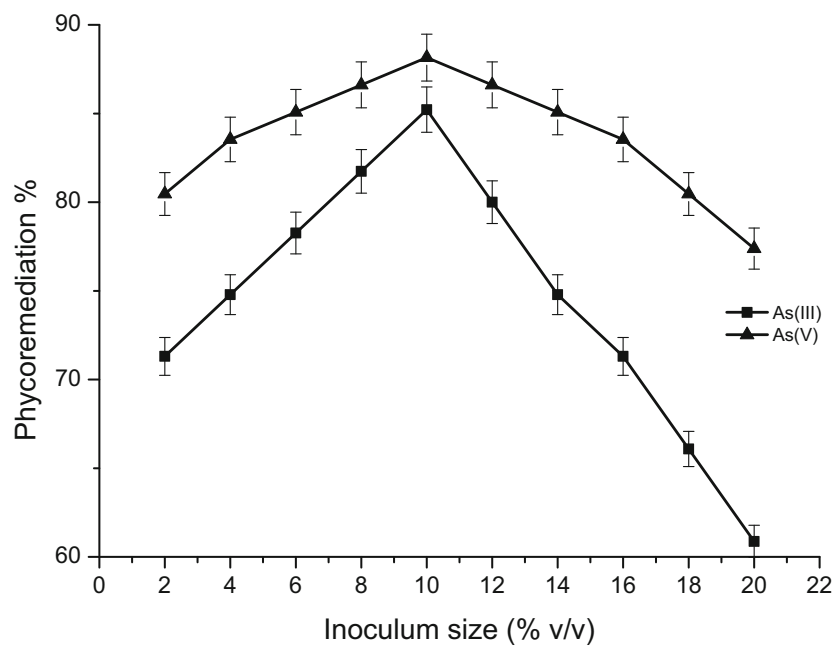

Fig. 4 Effect of inoculum size on phycoremediation of $\mathrm{As}(\mathrm{III})$ and $\mathrm{As}(\mathrm{V})$ of $B$. braunii (initial $\mathrm{pH}, 9.0$; contact time, $144 \mathrm{~h}$; initial arsenic concentration, $50 \mathrm{mg} / \mathrm{L}$; temperature, $28{ }^{\circ} \mathrm{C}$ ). (Error bars represent means \pm standard errors from the mean of duplicate experiments). stationary phase starts after 14 days. While concentrations of $\mathrm{As}(\mathrm{III})$ and $\mathrm{As}(\mathrm{V})$ were at $>1000 \mathrm{mg} / \mathrm{L}$, microalgal growth was significantly inhibited with the lag phase increased to 4 days and the stationary phase starts after 14 days (Fig. 5). Thus to get an overall idea, experimentations was continued up to 16 days. Remarkably throughout the time span of 1-3 days, when exposed to $50-2000 \mathrm{mg} / \mathrm{L}$ of arsenic ions (either As(III) or As $(\mathrm{V}))$, the growth rate was $2.85-14 \%$ lower than that in arsenic-free medium, demonstrating that microalgal growth was encouraged by low concentrations of arsenic ions (either $\mathrm{As}(\mathrm{III})$ or $\mathrm{As}(\mathrm{V}))$ because of hormesis. For evaluating the toxicity of different inorganic arsenic species (either As(III) or $\mathrm{As}(\mathrm{V}))$ on $B$. braunii, the influence of increasing concentrations of arsenic (either $\mathrm{As}(\mathrm{III})$ or $\mathrm{As}(\mathrm{V})$ ) on the microalgal growth rate inhibition after 16th day was investigated.

Maximum biomass concentration and the specific growth rate of microalgae $B$. braunii in pure media were $3.231 \mathrm{~g} / \mathrm{L}$ and 0.148 day $^{-1}$, respectively. The maximum biomass concentration and specific growth rate of microalgae $B$. braunii in the presence of arsenic (either As(III) or As(V)) showed a declining trend, signifying that toxicity of media increased with increasing arsenic ion concentration.

With the increase in concentration of $\mathrm{As}(\mathrm{III})$ in the media from 50 to $2000 \mathrm{mg} / \mathrm{L}$, maximum biomass concentration reduced from 3.068 to $1.949 \mathrm{~g} / \mathrm{L}$ and the specific growth rate also reduced from 0.145 to 0.127 day $^{-1}$ because of toxicity of media by As(III) ions.

Similarly, increasing the concentration of $\mathrm{As}(\mathrm{V})$ from 50 to $2000 \mathrm{mg} / \mathrm{L}$, also led to decreased maximum biomass concentration from 3.062 to $1.955 \mathrm{~g} / \mathrm{L}$ and specific growth rate from 0.145 to 0.127 day $^{-1}$ also because of toxicity of media by $\mathrm{As}(\mathrm{V})$ ions.

The toxicity of As(III) and $\mathrm{As}(\mathrm{V})$ was found to be similar for the microalgae $B$. braunii because the maximum biomass concentration of $B$. braunii in the growth media was almost analogous in the presence of both $\mathrm{As}(\mathrm{III})$ and $\mathrm{As}(\mathrm{V})(\mathrm{pH} 9.0)$. $\mathrm{As}(\mathrm{V})$ and $\mathrm{As}(\mathrm{III})$ showed similar toxicity to freshwater alga S. bacillaris at $\mathrm{pH} 8.2$ with levels of phosphate between 0.03 and $0.3 \mathrm{mg} \mathrm{P} / \mathrm{L}$ [48]. Equal toxicity of As(III) and As(V) was assessed from the $72 \mathrm{~h}$ growth inhibition tests for another freshwater algal species Chlorella sp. (pH 7.6), while As(V) was more toxic than $\mathrm{As}(\mathrm{III})$ for M. arcuatum (pH 7.6) [46].

\section{Effect of Initial Arsenic Concentration on Chlorophyll Content}

Carotenoids and chlorophylls, which are present in plants and algae, are very essential for the photosynthesis and growth of microalgae [70]. Figure 6 shows the changes in chlorophyll content over the days of growth of microalgae $B$. braunii during incubation period in the presence of various concentrations of arsenic (either $\mathrm{As}(\mathrm{III})$ or $\mathrm{As}(\mathrm{V})$ ) ions. It was found that the total chlorophyll content increases significantly giving a 


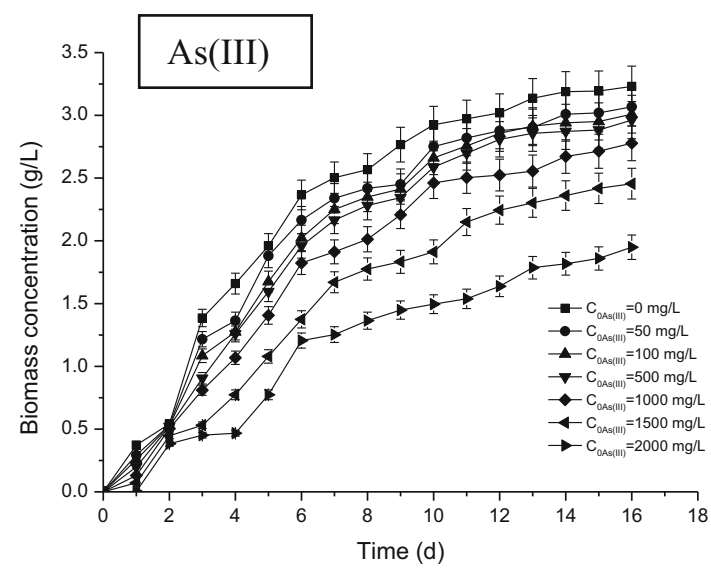

Fig. 5 Growth of B. braunii in absence and presence of increasing concentrations of biomass concentration of $\mathrm{As}(\mathrm{III})$ and $\mathrm{As}(\mathrm{V})$ (initial $\mathrm{pH}, 9.0$; inoculum size $(\%, v / v), 10$; initial arsenic concentration,

peak value on 14th day in all arsenic (either As(III) or As(V)) concentrations with the increase in days of incubation [20]. After the 14th day, there was no significant change in chlorophyll content in all the concentrations. Furthermore, the highest chlorophyll was recorded in absence of arsenic, followed by 50,100 , and so on up to $2000 \mathrm{mg} / \mathrm{L}$. The lowest chlorophyll was recorded in the media containing $2000 \mathrm{mg} / \mathrm{L}$.

Inhibited biosynthesis of chlorophyll and carotenoids and reduced phosphorylation are most commonly observed symptoms of metal toxicity [71, 72]. Overall, arsenic reduced the growth rate resulting in lower chlorophyll content in arsenicexposed biomass than in the control. It can be due to the fact that the photosynthetic enzymes activities reduce with high concentration of arsenic (either $\mathrm{As}(\mathrm{III})$ or $\mathrm{As}(\mathrm{V})$ ), which results in the decrease of chlorophyll content [73]. From the present study, it can be determined that certain concentration of arsenic (either $\mathrm{As}(\mathrm{III})$ or $\mathrm{As}(\mathrm{V}))$ inhibits the growth of microalgae, produces low chlorophyll in the microalgae, and disturbs the photosynthetic activities. Such decreases in the levels of photosynthetic pigments, including chlorophyll $a$ and $b$ and

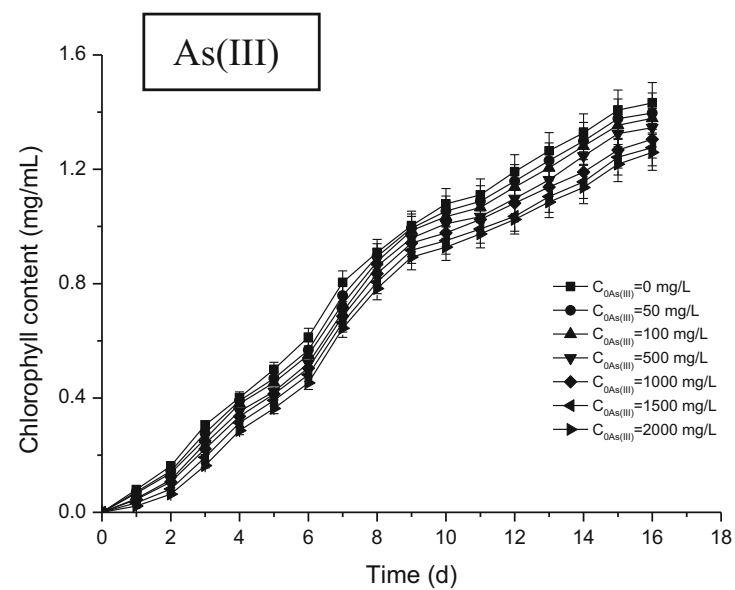

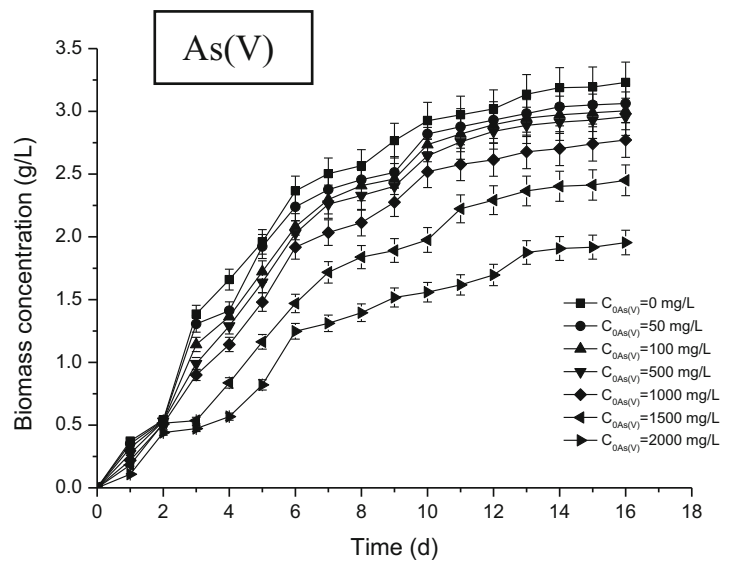

$50 \mathrm{mg} / \mathrm{L}$; temperature, $28^{\circ} \mathrm{C}$; incubation time, 16 days; dark/light period, $12: 12 \mathrm{~h}$ ). (Error bars represent means \pm standard errors from the mean of duplicate experiments).

accessory pigments, such as carotenoids of some mosses, on exposure to heavy metals was also observed by Shakya et al. [74].

\section{Effect of Contact Time on Phycoremediation of Arsenic}

Figure 7 presents the effect of contact time on the phycoremediation \% of $\mathrm{As}(\mathrm{IIII})$ and $\mathrm{As}(\mathrm{V})$ using microalgae. The phycoremediation \% of both $\mathrm{As}(\mathrm{III})$ and $\mathrm{As}(\mathrm{V})$ was found to increase from 40 to 85.217 and 42 to 88.154 , respectively, when contact time was varied from 4 to $144 \mathrm{~h}$. Time required to for achieve equilibrium was $144 \mathrm{~h}$ for both $\mathrm{As}(\mathrm{III})$ and $\mathrm{As}(\mathrm{V})$ ions. Hence, further phycoremediation studies were continued for a contact time of $144 \mathrm{~h}$.

The study reveals the high potential of the $B$. brunii in the elimination of both $\mathrm{As}(\mathrm{III})$ and $\mathrm{As}(\mathrm{V})$ from synthetic wastewater. An S-shaped growth curve was observed for both $\mathrm{As}(\mathrm{III})$ and $\mathrm{As}(\mathrm{V})$. This characterizes the effective growth of $B$. brunii biomass in synthetic wastewater. From the consequences, it is clear that in all the systems, the saturation time

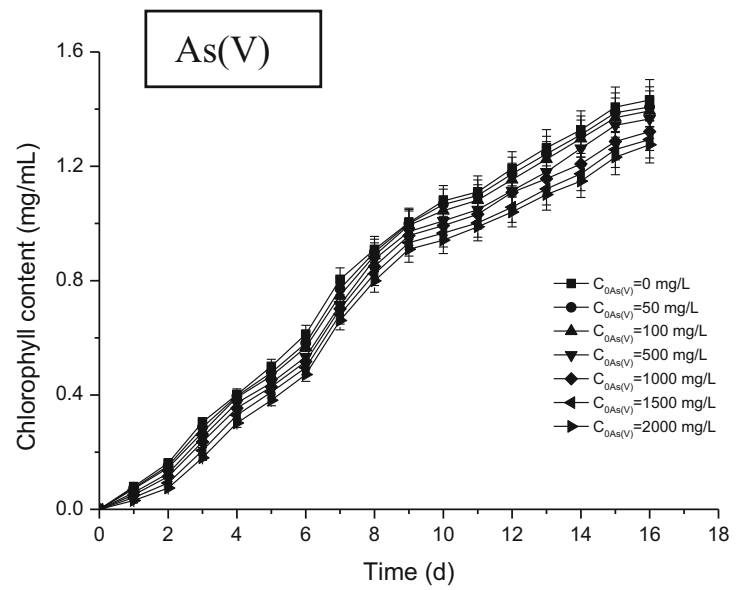

Fig. 6 Variation in chlorophyll content in B. braunii at different times of exposure under different concentrations of As(III) and As(V). (Error bars represent means \pm standard errors from the mean of duplicate experiments) 


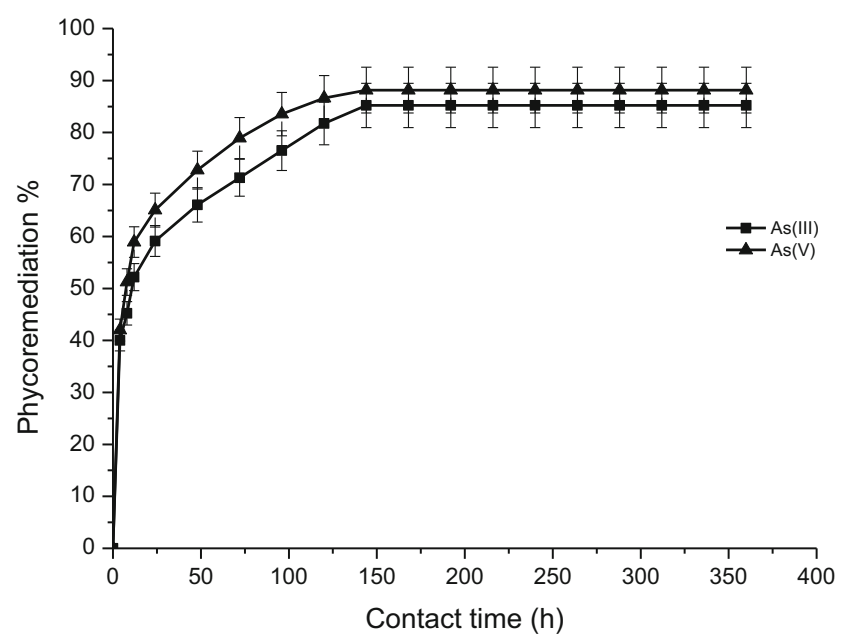

Fig. 7 Effect of contact time on phycoremediation of $\mathrm{As}(\mathrm{III})$ and $\mathrm{As}(\mathrm{V})$ of $B$. braunii (initial $\mathrm{pH}, 9.0$; inoculum size $(\%, v / v), 10$; initial arsenic concentration, $50 \mathrm{mg} / \mathrm{L}$; temperature, $28{ }^{\circ} \mathrm{C}$ ). (Error bars represent means \pm standard errors from the mean of duplicate experiments).

cannot be ruled by the adsorbate concentration in the solution. The change in the rate of phycoremediation might be owing to the fact that originally all sites of algal biomass surfaces are readily available and moreover the concentration gradient of adsorbate is very high. At optimum $\mathrm{pH}$, the fast kinetics of interaction of adsorbate-algal biomass might be obvious to increase availability of the active sites of the algal biomass surface. Therefore, the phycoremediation of adsorbate was fast in the early stages and progressively decreases with the interval of time until equilibrium in each case. The reduction in elimination of metal ions at the later stage of the process was due to the falling in concentration of metal ions [75]. Consequently, the curves found were single, smooth, and continuous leading to equilibrium and suggested the possibility of phycoremediation of the adsorbate on the surface of microalgal cells [51].

The results of the effect of contact time on removal identified that the respective algae had an optimum residence time for $\mathrm{As}(\mathrm{III})$ and $\mathrm{As}(\mathrm{V})$ and when this time passed, the removal either become almost constant or diminished slightly. The constant nature of the phycoremediation \% curve after $144 \mathrm{~h}$ for both $\mathrm{As}(\mathrm{III})$ and $\mathrm{As}(\mathrm{V})$ may be owing to initiation of the stationary phase of the microalgae $B$. braunii.

\section{Effect of Initial As(III) and As(V) Concentration on Phycoremediation of Arsenic}

The effect of initial metal ion concentration on phycoremediation of arsenic using $B$. braunii was carried out by varying phosphate concentrations $(50,100,200,500$, $800,1000,1200,1500,1800$, and $2000 \mathrm{mg} / \mathrm{L}$ ) in the growth media, at an initial optimized $\mathrm{pH}$ value of 9.0 are shown in Fig. 8.

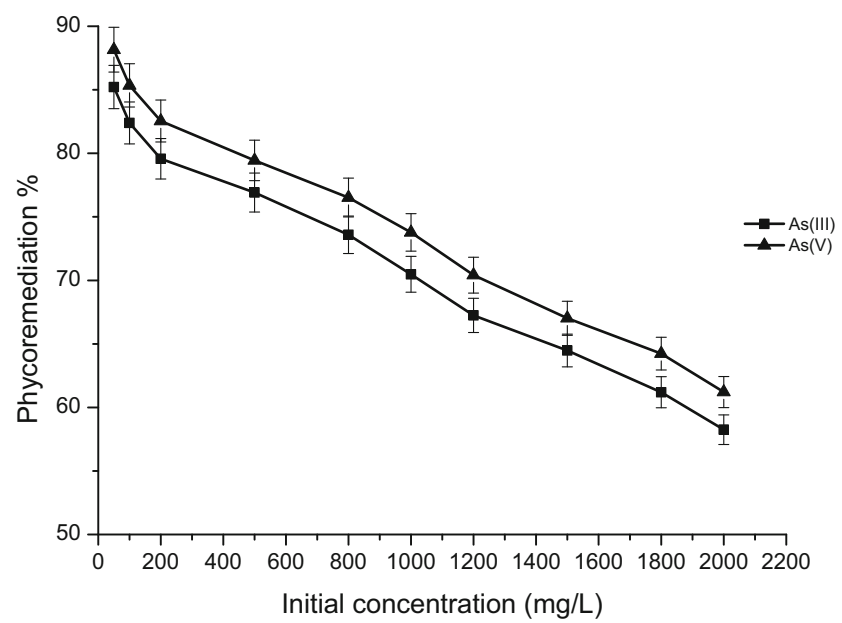

Fig. 8 Effect of initial arsenic concentration on phycoremediation of $\mathrm{As}(\mathrm{III})$ and $\mathrm{As}(\mathrm{V})$ of $B$. braunii (initial $\mathrm{pH}, 9.0$; inoculum size $(\%, v / v)$, 10; contact time, $144 \mathrm{~h}$; temperature, $28^{\circ} \mathrm{C}$ ). (Error bars represent means \pm standard errors from the mean of duplicate experiments).

The phycoremediation \% decreased with the increase in arsenic (As(III)/As(V)) concentration from 50 to $2000 \mathrm{mg} / \mathrm{L}$. It was supported by the decrease in microalgal growth. The reduction in phycoremediation \% of $\mathrm{As}(\mathrm{III})$ and $\mathrm{As}(\mathrm{V})$ was caused by the toxicity of $\mathrm{As}(\mathrm{III})$ and $\mathrm{As}(\mathrm{V})$ at higher concentrations which decreased the biomass concentration. The maximum biomass concentration was found to decrease from 3.068 to $1.949 \mathrm{~g} / \mathrm{L}$ with the increase in As(III) concentration from 50 to $2000 \mathrm{mg} / \mathrm{L}$. Varying the concentration of As(III) from 50 to $2000 \mathrm{mg} / \mathrm{L}$ resulted in an increased phycoremediation levels from 42.609 to $1165 \mathrm{mg} / \mathrm{L}$.

Similarly, the maximum biomass concentration was found to decrease from 3.062 to $1.955 \mathrm{~g} / \mathrm{L}$ with the increase in $\mathrm{As}(\mathrm{V})$ concentration from 50 to $2000 \mathrm{mg} / \mathrm{L}$. Varying the concentration of $\mathrm{As}(\mathrm{V})$ from 50 to $2000 \mathrm{mg} / \mathrm{L}$ also resulted in an increased phycoremediation levels from 44.077 to $1224.192 \mathrm{mg} / \mathrm{L}$.

The elimination of $\mathrm{As}(\mathrm{V})$ is higher than $\mathrm{As}(\mathrm{III})$ for all concentrations due to more production of phytochelatins in cells after exposure to $\mathrm{As}(\mathrm{V})$ than to $\mathrm{As}(\mathrm{III})$ [48].

\section{Effect of Phosphate Concentration on Growth Properties of B. braunii in Arsenic-Free Media}

Macronutrient such as phosphorous also plays a major role to control the metabolism and finally the growth of microalgae $[20,76]$. The effect of phosphate ion concentration on the growth rate of microalgae $B$. braunii in arsenic-free media was explored in the phosphate concentration range of 0.005 $0.05 \mathrm{~g} / \mathrm{L}$ keeping other compositions constant as prescribed in the BG11 medium, at $\mathrm{pH} 9.0$ and at a temperature of $28^{\circ} \mathrm{C}$. As presented in Fig. 9, the relationship of biomass concentration to phosphate ion concentration for microalgae $B$. braunii, often adopted the saturation kinetics form. It was observed that 


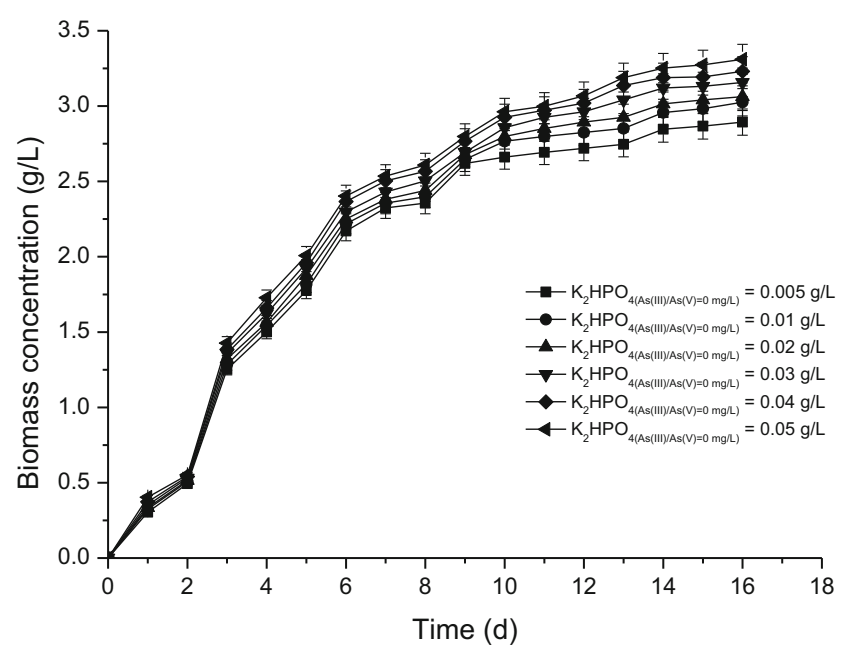

Fig. 9 Effect of phosphate concentration on growth of microalgae B. braunii in arsenic free media (initial $\mathrm{pH}, 9.0$; inoculum size $(\%, v / v)$, 10 ; temperature, $28{ }^{\circ} \mathrm{C}$; incubation time, 16 days; dark/light period, 12:12 h). (Error bars represent means \pm standard errors from the mean of duplicate experiments)

biomass concentration increased with increasing initial phosphate ion concentration from 0.005 to $0.5 \mathrm{~g} / \mathrm{L}$. Phosphorus typically constitutes $1 \%$ of dry weight of algae [77], but it may be essential in significant excess because not all added phosphate is bioavailable because of the formation of complexes with metal ions [78]. Immediate effects of phosphorus limitation include a decrease in the synthesis and regeneration of substrates in the Calvin-Benson cycle and a significant decrease in the rate of light utilization necessary for carbon fixation [79]. Phosphorus starvation reduces chlorophyll $a$ and protein content [38]. Phosphate deficiency was revealed to result in accumulation of astaxanthin and an overall reduction in cell growth [80]. It was observed that the specific growth rate increased from 0.146 to $0.148 \mathrm{day}^{-1}$, with an increase in phosphate concentration from 0.005 to $0.05 \mathrm{~g} / \mathrm{L}$ and biomass concentration of microalgae B. braunii increased from 2.893 to $3.31 \mathrm{~g} / \mathrm{L}$.

\section{Effect of Phosphate Concentration Microalgal Growth in Arsenic-Containing Media}

The effect of increasing phosphate concentrations on growth properties of microalgae $B$. braunii in $50 \mathrm{mg} / \mathrm{L}$ of arsenic (either $\mathrm{As}(\mathrm{IIII})$ or $\mathrm{As}(\mathrm{V}))$ containing media was studied in the range from 0.005 to $0.05 \mathrm{~g} \mathrm{P} / \mathrm{L}$ under same experimental conditions.

The present studies supported the result that phosphate limited cells were more sensitive to arsenic exposure, possibly because arsenic toxicity interfered with phosphate metabolism, leading to depletion of phosphate or inhibition of adenosine triphosphate production (ATP) [46]. As(V) enters the microalgal cell via phosphate transporters due to its chemical similarity to phosphate [81]. Thus, under low phosphate condition, the smaller amount of phosphate may not be adequate to compete with $\mathrm{As}(\mathrm{V})$ in the outer cell transporting system [72]. However, increasing phosphate concentrations reduced the toxicity of both $\mathrm{As}(\mathrm{III})$ and $\mathrm{As}(\mathrm{V})$ in a similar way (Fig. 10).

The growth rate and maximum biomass concentration of microalgae $B$. braunii increased from 0.14 day $^{-1}$ and $2.698 \mathrm{~g} /$ $\mathrm{L}$ to $0.145 \mathrm{day}^{-1}$ and $3.136 \mathrm{~g} / \mathrm{L}$ (As(III) and from 0.139 day $^{-1}$ and $2.793 \mathrm{~g} / \mathrm{L}$ to $0.145 \mathrm{day}^{-1}$ and $3.126 \mathrm{~g} / \mathrm{L}(\mathrm{As}(\mathrm{V}))$, respectively with increasing initial phosphate concentration from 0.005 to $0.05 \mathrm{~g} / \mathrm{L}$ in the presence of arsenic ions (either $\mathrm{As}(\mathrm{III})$ or $\mathrm{As}(\mathrm{V}))$. It was clear from the results of the present study that initial nitrate concentration played a major role in the microalgal growth and decreased the inhibitory effects of arsenic on the microalgal growth.

The reduction in inorganic arsenic toxicity was perhaps related to the reduced intracellular As(III) and $\mathrm{As}(\mathrm{V})$ contents in cells grown in phosphate-enriched BG11 growth media. The addition of $0.04 \mathrm{mg} \mathrm{P} / \mathrm{L}$ as phosphate to BG11 growth media resulted in a $12 \%$ increase in biomass concentration in algae exposed to $50 \mathrm{mg} / \mathrm{L}$ of arsenic (either $\mathrm{As}(\mathrm{III})$ or $\mathrm{As}(\mathrm{V})$ ). Karadjova et al. [47] described that seawater enrichment with phosphate (up to $1.3 \mathrm{mg} \mathrm{P} / \mathrm{L}$ ) resulted in a remarkable reduction of toxicity because of $\mathrm{As}(\mathrm{III})$ and $\mathrm{As}(\mathrm{V})$. A reduction in the $\mathrm{As}(\mathrm{V})$ toxicity was observed for freshwater algae Chlorella sp. and M. arcuatum in culture medium containing $0.5 \mathrm{mg} \mathrm{P} / \mathrm{L}$ [46]. On the other hand, extremely high phosphate concentrations $(9.1 \mathrm{mg} \mathrm{P} / \mathrm{L})$ did not protect the cells of Chlorella sp. isolated from arsenic contaminated sites from arsenate stress [82].

\section{Modeling of Growth Kinetics of Algal Biomass in Presence Various Concentration of Phosphate Ions}

The growth of the microalgae was investigated in batch culture by varying the quantity of phosphate ions $\left(\mathrm{K}_{2} \mathrm{HPO}_{4}\right)$ in the range of $0.005-0.05 \mathrm{~g} / \mathrm{L}$ in pure and $50 \mathrm{mg} / \mathrm{L}$ of arseniccontaining (either As(III) or As(V)) media. The experimental values of dry biomass obtained all through the experimentation period for different values of $\mathrm{K}_{2} \mathrm{HPO}_{4}$ in pure and $50 \mathrm{mg} /$ $\mathrm{L}$ of arsenic-containing (either $\mathrm{As}(\mathrm{III})$ or $\mathrm{As}(\mathrm{V})$ ) media have been plotted in Fig. 11. The classical Monod equation was employed for representing the growth of the microalgae $B$. braunii in pure and arsenic (either $\mathrm{As}(\mathrm{III})$ or $\mathrm{As}(\mathrm{V})$ ) media during exponential phase only. Maximum specific growth rate and saturation constant have also been estimated by non-linear regression analysis utilizing professional graphics software package OriginPro (8.5.1 version) for fitting the experimental data obtained during the batch study. In case of pure media, the value of $\mu_{\max }$ was 0.148 day $^{-1}$ and that of $K_{s}$ was $7.01 \mathrm{E}$ $-05 \mathrm{~g} / \mathrm{L}$ (correlation coefficient is equal to 0.982 ). The plot showed that moderate addition of arsenic increased $K_{s}$ to $2.162 \mathrm{E}-04 \mathrm{~g} / \mathrm{L}$ (correlation coefficient is equal to 0.98 ) for 


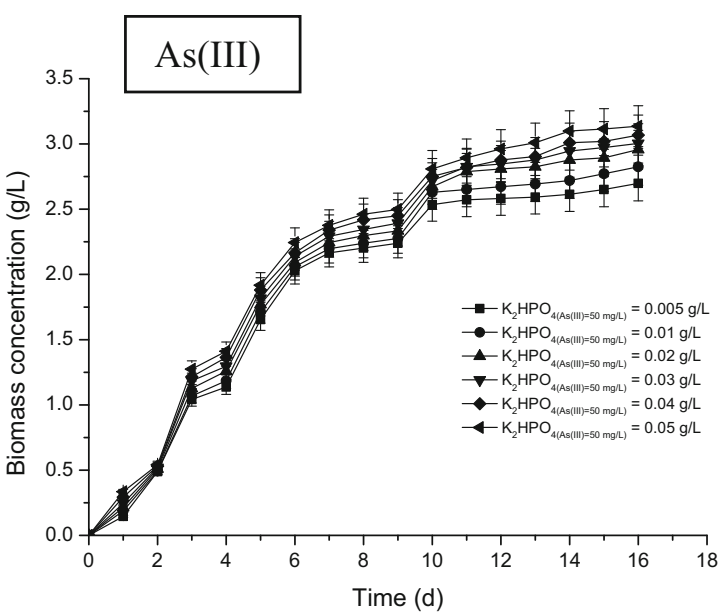

Fig. 10 Effect of phosphate concentration on growth of microalgae B. braunii in arsenic-enriched media (initial $\mathrm{pH}, 9.0$; inoculum size $(\%$, $v / v), 10$; initial arsenic concentration, $50 \mathrm{mg} / \mathrm{L}$; temperature, $28{ }^{\circ} \mathrm{C}$;

As(III) and that to $2.534 \mathrm{E}-04 \mathrm{~g} / \mathrm{L}$ (correlation coefficient is equal to 0.997$)$ for $\mathrm{As}(\mathrm{V})$, without significantly influencing $\mu_{\max }(0.146$ for $\mathrm{As}(\mathrm{III})$ and 0.146 for $\mathrm{As}(\mathrm{V})$, respectively. The specific growth rate showed little variation in growth rates in the presence of arsenic $(\mathrm{As}(\mathrm{III}) / \mathrm{As}(\mathrm{V}))$. It indicates that the toxicity of arsenic (both $\mathrm{As}(\mathrm{III})$ and $\mathrm{As}(\mathrm{V})$ ) was reduced by increased concentrations of phosphate. This is similar to results described by Sanders [83] for the diatom Skeletonema costatum, that exhibited that growth rates were not affected by phosphate concentrations over a range of arsenic concentrations from 5 to $25 \mu \mathrm{g} / \mathrm{L}$. Foster et al. [84] also reported that $P$. tricornutum showed small deviation in growth rates over the three phosphate concentrations $(3,1.2$, and $0.5 \mathrm{mg} / \mathrm{L})$ in the presence of $2 \mu \mathrm{g} / \mathrm{L} \mathrm{As}(\mathrm{V})$ ions.

Microbial growth in the medium containing no arsenic ions (either $\mathrm{As}(\mathrm{III})$ or $\mathrm{As}(\mathrm{V}))$, $\mathrm{As}(\mathrm{III})$ ions and $\mathrm{As}(\mathrm{V})$ ions was

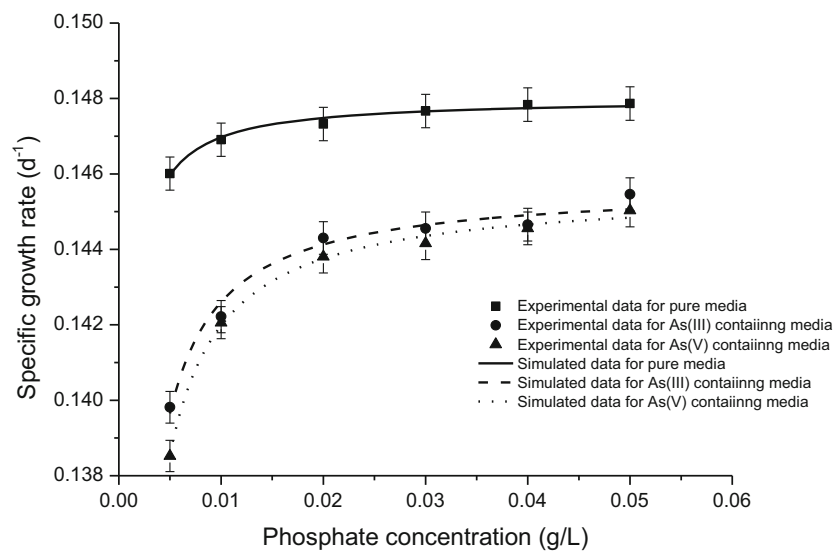

Fig. 11 Effect of phosphate concentration on growth kinetics of microalgal biomass (initial $\mathrm{pH}, 9.0$; inoculum size $(\%, v / v), 10$; temperature, $28{ }^{\circ} \mathrm{C}$; incubation time, 16 days; dark/light period, 12:12 h). (Error bars represent means \pm standard errors from the mean of duplicate experiments)

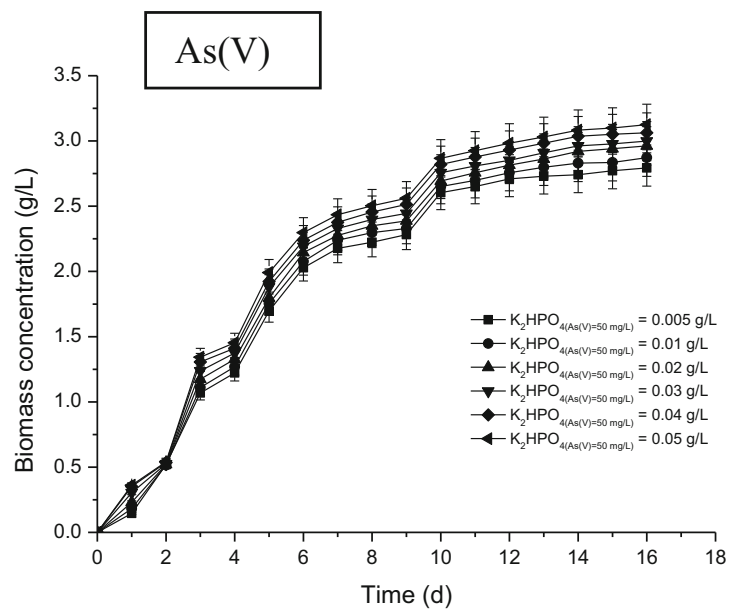

incubation time, 16 days; dark/light period, 12:12 h). (Error bars represent means \pm standard errors from the mean of duplicate experiments)

described with the following Monod Eq. (3), Eq. (4), and Eq. (5), respectively:

$$
\begin{aligned}
\mu & =\frac{0.148 C_{A}}{\left(7.01 \mathrm{E}-05+C_{A}\right)} \\
\mu & =\frac{0.146 C_{A}}{\left(2.162 \mathrm{E}-04+C_{A}\right)} \\
\mu & =\frac{0.146 C_{A}}{\left(2.534 \mathrm{E}-04+C_{A}\right)}
\end{aligned}
$$

\section{Effect of Phosphate Concentration on Phycoremediation of Arsenic}

The effect of phosphate on phycoremediation of arsenic using $B$. braunii was carried out by varying phosphate concentrations $(0.005,0.01,0.02,0.03,0.04$, and $0.05 \mathrm{~g} / \mathrm{L})$ in the growth media containing $50 \mathrm{mg} / \mathrm{L}$ of arsenic (either As(IIII) or $\mathrm{As}(\mathrm{V})$ ), at an initial optimized $\mathrm{pH}$ value of 9.0 at $28{ }^{\circ} \mathrm{C}$ temperature under the same experimental conditions are shown in Fig. 12.

The phycoremediation \% of both $\mathrm{As}(\mathrm{III})$ and $\mathrm{As}(\mathrm{V})$ increased with the increase in phosphate concentration from 0.005 to $0.5 \mathrm{~g} / \mathrm{L}$. It was supported by the increase in microalgal growth. The increase in phycoremediation $\%$ of $\mathrm{As}(\mathrm{III})$ and $\mathrm{As}(\mathrm{V})$ was caused by the reduction of toxicity of $\mathrm{As}(\mathrm{III})$ and $\mathrm{As}(\mathrm{V})$ at higher phosphate concentration which increased the biomass concentration. The maximum biomass concentration was found to increase from 3.068 to $1.949 \mathrm{~g} / \mathrm{L}$ in the presence of As(III) and also from 3.068 to $1.949 \mathrm{~g} / \mathrm{L}$ in the presence of $\mathrm{As}(\mathrm{V})$ with the increase in phosphate concentration from 0.005 to $0.5 \mathrm{~g} / \mathrm{L}$. It can also be explained by the following fact. 


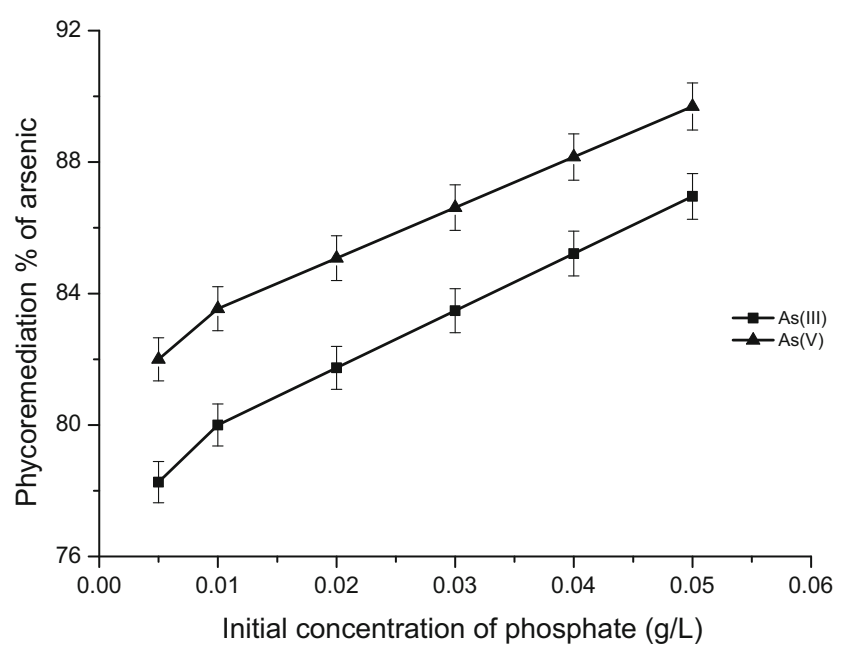

Fig. 12 Effect of initial phosphate concentration on phycoremediation of $\mathrm{As}(\mathrm{III})$ and $\mathrm{As}(\mathrm{V})$ of $B$. braunii (initial $\mathrm{pH}, 9.0$; inoculum size $(\%, v / v)$, 10; contact time, $144 \mathrm{~h}$; temperature, $28^{\circ} \mathrm{C}$ ). (Error bars represent means \pm standard errors from the mean of duplicate experiments)

Both phosphate and arsenic are located in the same main group, and the molecular structure of the phosphate ion is very similar to that of the arsenic ion. So phosphate caused a higher reduction in arsenic phycoremediation, because the existing phosphate ions must strongly contend with arsenic ions for active binding sites on the surfaces of microalgae [85]. Though both divalent $\mathrm{As}(\mathrm{V})$ and phosphate anions are capable to form hydrogen bonding with $\mathrm{MOH}_{2}^{+}$and $\mathrm{M}-\mathrm{NH}^{3+}$, the basicity of divalent $\mathrm{As}(\mathrm{V})$ is very similar to that of divalent phosphate since both parent acids have very close values of $\mathrm{p} K_{\mathrm{a} 1}, \mathrm{p} K_{\mathrm{a} 2}$, and $\mathrm{p} K_{\mathrm{a} 3}$. Then the noteworthy difference does not exist in strength of the hydrogen bonding of each anion with $\mathrm{MOH}_{2}^{+}$and $\mathrm{M}-\mathrm{NH}^{3+}$, between $\mathrm{HAsO}_{4}{ }^{2-}$ and $\mathrm{HPO}_{4}{ }^{2-}$ species. Conversely, significant difference can be observed between ionic sizes and charge density of both anions. In $\mathrm{HAsO}_{4}{ }^{2-}$, lengths of three equivalent As-O bonds are 0.1654-0.1671 nm and As- $\mathrm{O}$ bond length in As- $\mathrm{OH}$ is $0.1742 \mathrm{~nm}$ [86]. Similarly of $\mathrm{HPO}_{4}{ }^{2-}$, lengths of three equivalent $\mathrm{P}-\mathrm{O}$ bonds are $0.1510-0.1524 \mathrm{~nm}$ and $\mathrm{P}-\mathrm{O}$ bond length in $\mathrm{P}-\mathrm{OH}$ is $0.1551-0.1564 \mathrm{~nm}$ [87]. Then again the ionic radii of phosphate $(0.17 \AA)$ are also smaller than $\mathrm{As}(\mathrm{V})$ $(0.335 \AA)$ [88]. Thus crystallographic size or ionic radii of divalent phosphate anion is smaller than that of divalent $\mathrm{As}(\mathrm{V})$ anion and bear high charge density of divalent phosphate anion [89]. Below pH 5.0, the monovalent phosphate species $\left(\mathrm{H}_{2} \mathrm{PO}_{4}{ }^{-}\right)$was prevailing and above $\mathrm{pH}$ 5.0, the dominant species of divalent phosphate species $\left(\mathrm{HPO}_{4}{ }^{2-}\right)$ raised and phosphate phycoremediation also increased [90]. So phycoremediation of $\mathrm{As}(\mathrm{V})$ decreased in this $\mathrm{pH}$ range. Furthermore, it is assessed that Coulombic interaction between phosphate and positive sites is more than that in case of $\mathrm{As}(\mathrm{V})$, resulting in stronger interaction of phosphate with positive site than $\operatorname{As}(\mathrm{V})$. So phosphate might overcome $\mathrm{As}(\mathrm{V})$ in competition for overall binding with positive sites [90]. The results in Fig. 12 exhibited As(III) removal was also influenced to a similar extent by phosphate oxyanions [91].

\section{Characterization of Microalgae}

\section{SEM-EDX}

Figure 13a-c shows the scanning electron microscopy (SEM) images of native microalgal biomass and As(III)- and As(V)loaded microalgal biomasses, respectively. In both images, two types of structure have been seen. The spherical shape represents B. braunii [92]. By comparing Fig. 13a-c, it is found that in native microalgal biomass, the surface is smooth while after arsenic (either $\mathrm{As}(\mathrm{III})$ or $\mathrm{As}(\mathrm{V})$ ) treatment, the surface becomes rough in both the microalgal structures. Such roughness of the surface may be because of the phycoremediation of arsenic (either As(III) or As(V)) over the surface that makes the surface coarser than its original form. It has also been seen that there has been very little or no change in the fraction of spherical shape of B. braunii before and after arsenic (either $\mathrm{As}(\mathrm{III})$ or $\mathrm{As}(\mathrm{V})$ ) removal. It recommends that the presence of arsenic (either As(III) or $\mathrm{As}(\mathrm{V}))$ does not make the medium selective toward any of the strains and the biological nature of the consortium remains fairly constant. Densities of the nodules also seem to be unaffected by the presence of arsenic (either $\mathrm{As}(\mathrm{III})$ or $\mathrm{As}(\mathrm{V})$ ) signifying that the growth kinetics of the consortium remains unaffected in the presence of arsenic (either $\mathrm{As}(\mathrm{III})$ or $\mathrm{As}(\mathrm{V})$ ) in simulated wastewater. But, the nodules are not clearly visible in the SEM. The cells seem to be glued to each other. It was because of more EPS production, which is one of the well-known responses against stress.

The corresponding EDX spectra of the unloaded and loaded microalgae was collected and given in Fig. 9a-c. The presence of arsenic on the loaded microalgae surface was exposed evidently. This outcome again established the occurrence of phycoremediation of arsenic by the microalgae.

\section{FT-IR Analysis}

The Fourier transform infrared (FT-IR) spectra of the B. braunii biomass with and without $\mathrm{As}(\mathrm{III})$ and $\mathrm{As}(\mathrm{V})$ ions loaded which were achieved to determine the possible functional groups, may have contributed to the phycoremediation of $\mathrm{As}(\mathrm{III})$ and $\mathrm{As}(\mathrm{V})$ ions, are presented in Fig. 14 and Table 6. The FT-IR spectra of the $B$. braunii biomass without As(III) and $\mathrm{As}(\mathrm{V})$ ions loaded exhibited a number of absorption peaks, indicating the complex nature of the microalgal biomass (Fig. 14). The spectra of unloaded and loaded with either As(III) or As(V) ions are compared and observed the 

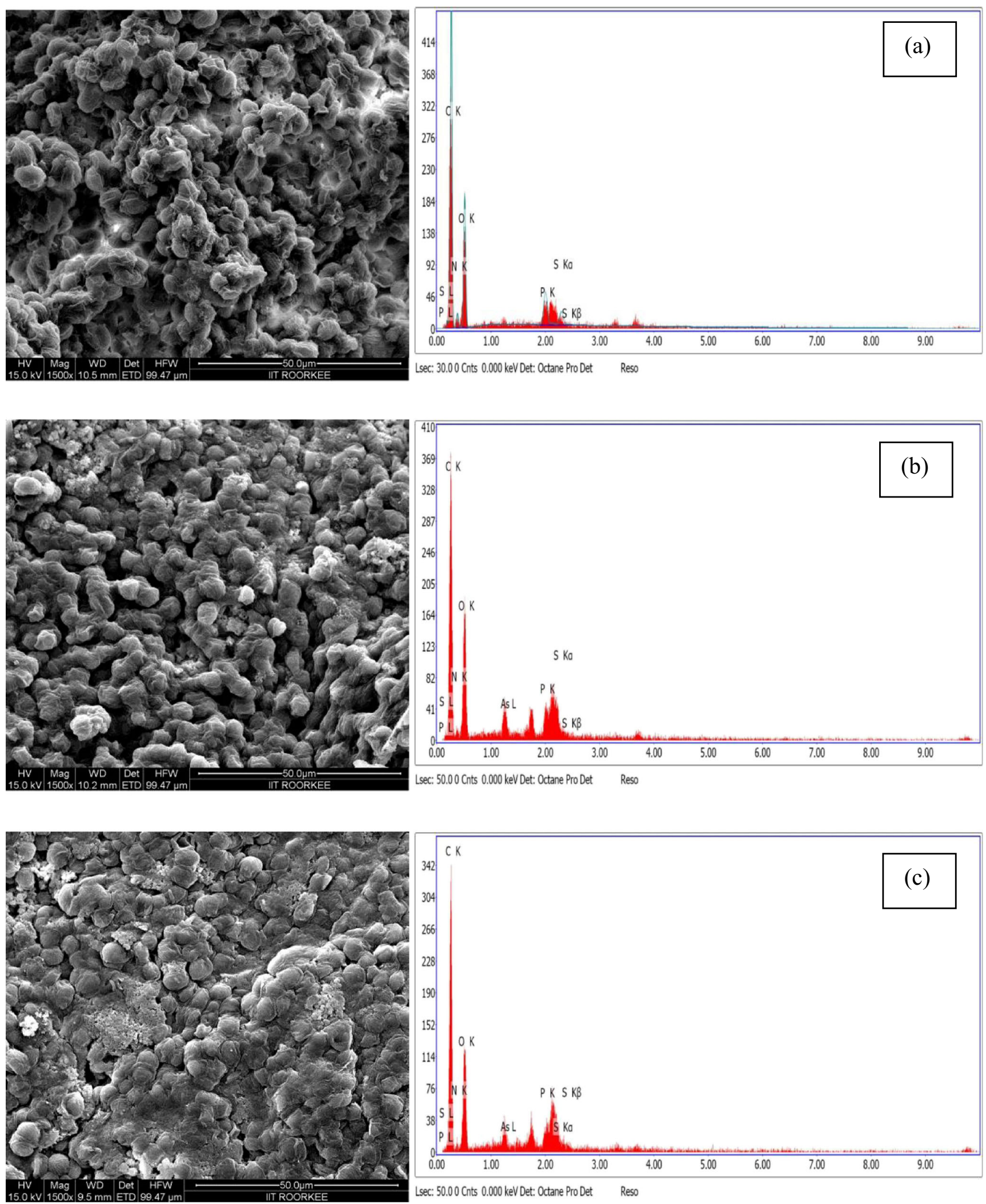

Fig. 13 Scanning electron micrographs $(\mathrm{SEM} ; \times 1500)$ and EDX of a native B. braunii biomass, b As(III)-loaded biomass, and $\mathbf{c}$ As(V)-loaded biomass

following shifting (Fig. 14; Table 6). The spectra of biomass exhibited an absorption band at $3370 \mathrm{~cm}^{-1}$ because of bonded
$-\mathrm{OH}$ and $-\mathrm{NH}$ stretching vibration which was shifted to $3430 \mathrm{~cm}^{-1}(\mathrm{As}(\mathrm{III}))$ and $3380 \mathrm{~cm}^{-1}(\mathrm{As}(\mathrm{V}))$ which may be 


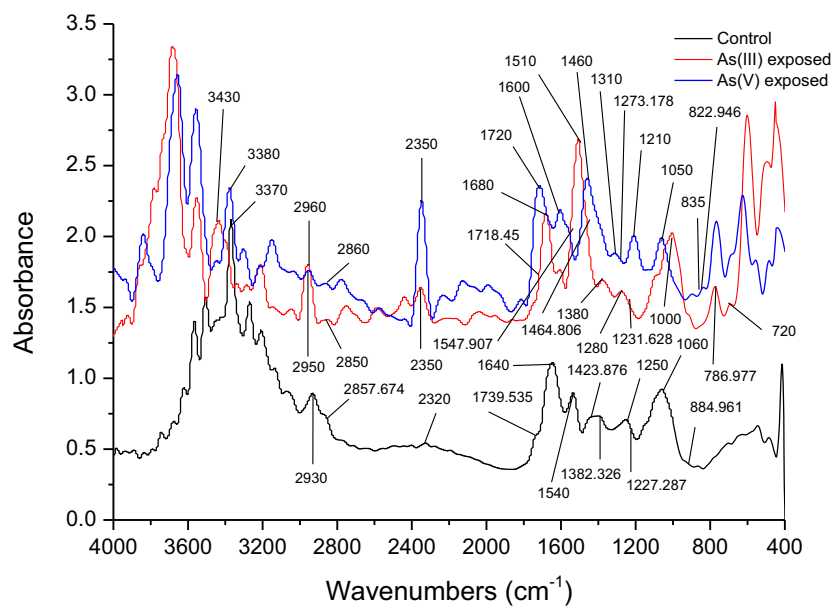

Fig. 14 FT-IR spectra of B. braunii control, As(III) ions exposed, and $\operatorname{As}(\mathrm{V})$ ions exposed

possibly because of the complexation of $-\mathrm{OH}$ and $-\mathrm{NH}$ groups with $\mathrm{As}(\mathrm{III})$ or $\mathrm{As}(\mathrm{V})$ ions $[93,94]$. Aliphatic $\mathrm{C}-\mathrm{H}$ stretching may be responsible for phycoremediation of $\mathrm{As}(\mathrm{III})$ and $\mathrm{As}(\mathrm{V})$ on the microalgal biomass as wavenumber shifted from 2930 to 2960 and $2950 \mathrm{~cm}^{-1}$, respectively, possibly because of the complexation with $\mathrm{As}(\mathrm{III})$ and $\mathrm{As}(\mathrm{V})$ ions [93]. Aldehyde C-H stretching may be responsible for As(III) and $\mathrm{As}(\mathrm{V})$ phycoremediation on $B$. braunii biomass as wavenumber shifted from 2857.674 to 2850 and also to $2860 \mathrm{~cm}^{-1}$, respectively [94]. The next absorption peaks at $2320 \mathrm{~cm}^{-1}$ has been shifted at a lower frequency to $2350 \mathrm{~cm}^{-1}$ (As(III)) and $2350 \mathrm{~cm}^{-1}(\mathrm{As}(\mathrm{V}))$, probably because of the complexation of $-\mathrm{CH}$ stretching vibration of alkyl chains [12]. Table 6 also shows the responsibility of aliphatic acid $\mathrm{C}=\mathrm{O}$ stretching for $\mathrm{As}(\mathrm{III})$ and $\mathrm{As}(\mathrm{V})$ phycoremediation by shifting the wavenumber from 1739.535 to 1718.45 and to $1720 \mathrm{~cm}^{-1}$, respectively [94]. The next adsorption peaks at $1640 \mathrm{~cm}^{-1}$ shifted to $1680 \mathrm{~cm}^{-1}$ for $\mathrm{As}(\mathrm{III})$ and $1600 \mathrm{~cm}^{-1}$ for $\mathrm{As}(\mathrm{V})$, perhaps because of the complexation of amide group ( $\mathrm{N}-\mathrm{H}$ stretching and $\mathrm{C}=\mathrm{O}$ stretching vibration) with $\mathrm{As}(\mathrm{III})$ and $\mathrm{As}(\mathrm{V})$ ions $[12,93]$. Wavenumber shifted from 1540 to $1510 \mathrm{~cm}^{-1}$ (As(III)) and $1547.907 \mathrm{~cm}^{-1}$ (As(V)), probably because of the complexation of secondary amine group with $\mathrm{As}(\mathrm{III})$ and $\mathrm{As}(\mathrm{V})$ ions [93]. Another shift was found from 1423.876 to $1464.806 \mathrm{~cm}^{-1}$ (As(III)) and $1460 \mathrm{~cm}^{-1}$ $(\mathrm{As}(\mathrm{V}))$, possibly due to the complexation of nitrogen with $\mathrm{As}(\mathrm{III})$ and $\mathrm{As}(\mathrm{V})$ ions of the $\mathrm{N}-\mathrm{H}$ group [95] and also due to the complexation with carboxyl groups [93]. Wavenumber shifted from 1382.326 to $1380 \mathrm{~cm}^{-1}$ (As(III)) and $1310 \mathrm{~cm}^{-1}$ $(\mathrm{As}(\mathrm{V}))$ assigned the reactivity of carboxylate anion $\mathrm{C}=\mathrm{O}$ stretching for the phycoremediation process [96]. Wavenumber shifted from 1250 to $1280 \mathrm{~cm}^{-1}$ (As(III)) and $1273.178 \mathrm{~cm}^{-1}(\mathrm{As}(\mathrm{V}))$ assigned the symmetric bending of $\mathrm{CH}_{3}$ group [93]. Wavenumber $1227.287 \mathrm{~cm}^{-1}$ shifted to $1231.628 \mathrm{~cm}^{-1}(\mathrm{As}(\mathrm{III}))$ and $1210 \mathrm{~cm}^{-1}(\mathrm{As}(\mathrm{V}))$ assigned for $-\mathrm{SO}_{3}$ stretching for the phycoremediation process [93]. The peaks at $1060 \mathrm{~cm}^{-1}$ may be attributed to the $\mathrm{C}-\mathrm{N}$ stretching vibrations of amino groups which was shifted and appeared at 1000 and $1039.460 \mathrm{~cm}^{-1}$, respectively, due to the interaction of nitrogen from the amino group with As(III) and $\mathrm{As}(\mathrm{V})$ ions [12]. The other weak adsorption peak shifted from 885.18 to $814.264 \mathrm{~cm}^{-1}$ (As(III)) and $896.744(\mathrm{As}(\mathrm{V}))$, corresponding to the $\mathrm{O}-\mathrm{C}-\mathrm{O}$ scissoring vibration of polysaccharide [97]. The presence of $\mathrm{As}(\mathrm{IIII})$ and $\mathrm{As}(\mathrm{V})$ on the microalgal biomass can be assured from the bands appeared at 721.24 and $819.845 \mathrm{~cm}^{-1}$, respectively $[29,98]$. It has to be cited here that a clear band was very hard to be got in the case of both $\mathrm{As}(\mathrm{III})$ and $\mathrm{As}(\mathrm{V})$. This may be because of different mechanisms involved in $\mathrm{As}(\mathrm{III})$ and $\mathrm{As}(\mathrm{V})$ phycoremediation. It
Table 6 Wavenumber $\left(\mathrm{cm}^{-1}\right)$ for the dominant peak from FT-IR for phycoremediation of $\mathrm{As}(\mathrm{III})$ and As(V)

\begin{tabular}{llll}
\hline Functional groups & $\begin{array}{l}\text { Native } \\
\text { biomass }\end{array}$ & $\begin{array}{l}\text { As(III) loaded } \\
\text { biomass }\end{array}$ & $\begin{array}{l}\text { As(V) loaded } \\
\text { biomass }\end{array}$ \\
\hline Surface O-H and N-H stretching & 3370 & 3430 & 3380 \\
Aliphatic C-H stretching & 2930 & 2960 & 2950 \\
Aldehyde C-H stretching & 2857.674 & 2850 & 2860 \\
-CH stretching vibration of alkyl chains & 2320 & 2350 & 2350 \\
Aliphatic acid C=O stretching & 1739.535 & 1718.45 & 1720 \\
Amide group (N-H stretching and C=O stretching vibration) & 1640 & 1680 & 1600 \\
Secondary amine group & 1540 & 1510 & 1547.907 \\
N-H group and carboxylate anion & 1423.876 & 1464.806 & 1460 \\
Carboxylate anion & 1382.326 & 1380 & 1310 \\
Symmetric bending of CH ${ }_{3}$ group & 1250 & 1280 & 1273.178 \\
$-\mathrm{SO}{ }_{3}$ stretching & 1227.287 & 1231.628 & 1210 \\
$\mathrm{C}-\mathrm{N}$ stretching vibrations of amino groups & 1060 & 1000 & 1050 \\
$\mathrm{O}-\mathrm{C}-\mathrm{O}$ scissoring vibration of polysaccharide & 884.961 & 786.977 & 835 \\
$\mathrm{As}(\mathrm{III})-\mathrm{O}$ & $\times$ & 720 & $\times$ \\
$\mathrm{As}(\mathrm{V})-\mathrm{O}$ & $\times$ & $\times$ & 822.946 \\
\hline
\end{tabular}


should be distinguished that the As-O band after phycoremediation of arsenic was not clearly observed because of the broad overlapping peaks in this region [99].

\section{Conclusions}

Fuel shortage in the near future poses a serious challenge; hence, a renewable energy resource having less environmental effect is necessary. Application of microalgae for such a purpose is an effective step. In the present study, an efficient microalgae $B$. braunii was found suitable for the elimination of both $\mathrm{As}(\mathrm{III})$ and $\mathrm{As}(\mathrm{V})$ from wastewater. A kinetic study has been performed in pure media as well as in simulated wastewater. The microalgae B. braunii removes 85.217 and $88.154 \%$ of $\mathrm{As}(\mathrm{III})$ and $\mathrm{As}(\mathrm{V})$, respectively, from the growth media supplemented with arsenic (either As(III) or As(V)) after $144 \mathrm{~h}$ of treatment with initial arsenic concentration of $50 \mathrm{mg} / \mathrm{L}$ at $\mathrm{pH} 9.0$ and inoculum size of $10 \%(\mathrm{v} / \mathrm{v})$. As $(\mathrm{V})$ was more toxic than As(III), particularly at the near-neutral pH 7.0, but at higher $\mathrm{pH}(\mathrm{pH} 9.0) \mathrm{As}(\mathrm{III})$ was much more toxic than $\mathrm{As}(\mathrm{V})$ to fresh microalage. A rise in phosphate concentration in the growth medium from 0.005 to $0.05 \mathrm{~g} \mathrm{P} / \mathrm{L}$ reduced the toxicity of $\mathrm{As}(\mathrm{III})$ and $\mathrm{As}(\mathrm{V})$. It was also supported by measuring the kinetic growth parameters. Value of $\mu_{\max }$ remained almost constant after addition of arsenic (either As(III) or $\mathrm{As}(\mathrm{V}))$, but the value of $K_{s}$ increased. Thus it can be stated that the microalgae $B$. braunii can be potentially employed as an effective biomaterial for arsenic remediation. The spent biomass can be applied for different aims, including the production of renewable energy source such as a number of biofuels like biomethane, bioethanol, biohydrogen, biobutanol, and the extraction of added value products like carotenoids or other bio-molecules for commercialization. However, this is a preliminary work involving a simulated solution of either $\mathrm{As}(\mathrm{III})$ and $\mathrm{As}(\mathrm{V})$ and a comprehensive study with real industrial wastewater encompassing a detailed parametric study in a continuous reactor system is needed.

\section{Nomenclature}

$C_{0} \quad$ initial concentration of arsenic in the solution $(\mathrm{mg} / \mathrm{L})$

$C_{\mathrm{f}}$ final concentration of arsenic in the solution $(\mathrm{mg} / \mathrm{L})$

$\mu \quad$ the specific growth rate $\left(\right.$ day $\left.^{-1}\right)$

$\mu_{\max }$ the maximum specific growth rate $\left(\right.$ day $\left.^{-1}\right)$

$C_{A}$ the limiting substrate concentration at time $t(\mathrm{~g} / \mathrm{L})$

$K_{s}$ the substrate saturation constant $(\mathrm{g} / \mathrm{L})$

Acknowledgments Our thanks to the Indian Institute of Technology, Roorkee for providing necessary facilities and to the Ministry of Human Resource Development, Government of India for financial support. The thoughtful comments by Prof. Meng Nan Chong, the Editor in Chief, and two anonymous reviewers are highly appreciated.

\section{References}

1. Mandal BK, Suzuki KT (2000) Arsenic round the world: a review. Talanta 58(1):201-235. doi:10.1016/S0039-9140(02)00268-0

2. Smedley PL, Kinniburgh DG (2002) A review of the source, behaviour and distribution of arsenic in natural waters. Appl Geochem 17(5):517-658. doi:10.1016/S0883-2927(02)00018-5

3. Mondal P, Majumder CB, Mohanty B (2006) Laboratory based approaches for arsenic remediation from contaminated water: recent developments. J Hazard Mater 137(1):464 479. doi:10.1016/j. jhazmat.2006.02.023

4. Mohan D, Pittman CU (2007) Arsenic removal from water/ wastewater using adsorbents - a critical review. J Hazard Mater 142(1):1-53. doi:10.1016/j.jhazmat.2007.01.006

5. Basha CA, Bhadrinarayana NS, Anantharaman N, Begum KM. Heavy metal removal from copper smelting effluent using electrochemical cylindrical flow reactor. J Hazard Mater 152(1): 71-78. doi: 10.1016/j.jhazmat.2007.06.069

6. A Ohki A, Nakayachigo K, Naka K, Maeda S. Adsorption of inorganic and organic arsenic compounds by aluminium-loaded coral limestone. Appl Organomet Chem 10(9):747-52. doi: 10.1002/ (SICI)1099-0739(199611)10:9<747::AID-AOC571>3.0.CO;2-Q

7. Ng JC. Environmental contamination of arsenic and its toxicological impact on humans. Environ Chem 2(3):146-160. doi: 10.1071/ EN05062.

8. WHO (1993) Guidelines for drinking water quality. World Health Organization, Geneva, p 41

9. European Commission Directive (1998) 98/83/EC, related with drinking water quality intended for human consumption, Brussels, Belgium

10. Babu BV, Gupta S (2008) Adsorption of Cr (VI) using activated neem leaves: kinetic studies. Adsorption 14(1):85-92. doi:10.1007/ s10450-007-9057-x

11. Renuka N, Sood A, Prasanna R, Ahluwalia AS (2015) Phycoremediation of wastewaters: a synergistic approach using microalgae for bioremediation and biomass generation. Int $\mathbf{J}$ Environ Sci Technol 12(4):1443-1460. doi:10.1007/s13762-0140700-2

12. Giri AK, Patel RK, Mahapatra SS (2011) Artificial neural network (ANN) approach for modelling of arsenic (III) biosorption from aqueous solution by living cells of Bacillus cereus biomass. Chem Eng J 178:15-25. doi:10.1016/j.cej.2011.09.111

13. Sarı A, Uluozlü ÖD, Tüzen M (2011) Equilibrium, thermodynamic and kinetic investigations on biosorption of arsenic from aqueous solution by algae (Mangeotia genuflexa) biomass. Chem Eng J 167(1):155-161. doi:10.1016/j.cej.2010.12.014

14. Giri AK, Patel RK, Mahapatra SS, Mishra PC (2013) Biosorption of arsenic (III) from aqueous solution by living cells of Bacillus cereus. Environ Sci Pollut Res 20(3):1281-1291. doi:10.1007/ s11356-012-1249-6

15. Franchino M, Comino E, Bona F, Riggio VA (2013) Growth of three microalgae strains and nutrient removal from an agrozootechnical digestate. Chemosphere 92(6):738-744. doi:10.1016/ j.chemosphere.2013.04.023

16. Olguín EJ, Sánchez-Galván G (2010) Aquatic phytoremediation: novel insights in tropical and subtropical regions. Pure Appl Chem 82(1):27-38. doi:10.1351/PAC-CON-09-02-13

17. Cai XH, Traina SJ, Logan TJ, Gustafson T, Sayre RT (1995) Applications of eukaryotic algae for the removal of heavy metals from water. Mol Mar Biol Biotech 4(4):338-344

18. Ting YP, Prince IG, Lawson F (1991) Uptake of cadmium and zinc by the alga Chlorella vulgaris: II. Multi-ion situation. Biotechnol Bioeng 37(5):445-455. doi:10.1002/bit.260370506

19. Hanumantha Rao P, Ranjith Kumar R, Raghavan BG, Subramanian VV, Sivasubramanian V (2011) Application of phycoremediation 
technology in the treatment of wastewater from a leather-processing chemical manufacturing facility. Water SA 37(1):7-14

20. Kushwaha D, Saha S, Dutta S (2014) Enhanced biomass recovery during phycoremediation of $\mathrm{Cr}(\mathrm{VI})$ using cyanobacteria and prospect of biofuel production. Ind Eng Chem Res 53(51):1975419764. doi:10.1021/ie501311c

21. Singh M, Reynolds DL, Das KC (2011) Microalgal system for treatment of effluent from poultry litter anaerobic digestion. Bioresour Technol 102(23):10841-10848. doi:10.1016/j.biortech. 2011.09.037, 102 10841-10848

22. Gupta V, Ratha SK, Sood A, Chaudhary V, Prasanna R. New insights into the biodiversity and applications of cyanobacteria (bluegreen algae) - prospects and challenges. Algal Res 2(2):79-97. doi: 10.1016/j.algal.2013.01.006

23. MasudHossain S, Anantharaman M (2006) Studies on bacterial growth and arsenic (III) biosorption using Bacillus subtilis. Chem Biochem Eng Q 20(2):209-216

24. Teclu D, Tivchev G, Laing M, Wallis M (2008) Bioremoval of arsenic species from contaminated waters by sulphate-reducing bacteria. Water Res 42(19):4885-4893. doi:10.1016/j.watres. 2008.09.010

25. Vaxevanidou K, Papassiopi N, Paspaliaris I (2008) Removal of heavy metals and arsenic from contaminated soils using bioremediation and chelant extraction techniques. Chemosphere 70(8): 1329-1337. doi:10.1016/j.chemosphere.2007.10.025, 70 13291337

26. Sarı A, Tuzen M (2009) Biosorption of As (III) and As (V) from aqueous solution by macrofungus (Inonotus hispidus) biomass: equilibrium and kinetic studies. J Hazard Mater 164(2):13721378. doi:10.1016/j.jhazmat.2008.09.047

27. Tuzen M, Sarı A, Mendil D, Uluozlu OD, Soylak M, Dogan M (2009) Characterization of biosorption process of As (III) on green algae Ulothrix cylindricum. J Hazard Mater 165(1):566-572. doi: 10.1016/j.jhazmat.2008.10.020

28. Yan L, Yin H, Zhang S, Leng F, Nan W, Li H (2010) Biosorption of inorganic and organic arsenic from aqueous solution by Acidithiobacillus ferrooxidans BY-3. J Hazard Mater 178(1):209217. doi:10.1016/j.jhazmat.2010.01.065, J Hazard Mater. 178 209-217

29. Aryal M, Ziagova M, Liakopoulou-Kyriakides M. Study on arsenic biosorption using Fe (III)-treated biomass of Staphylococcus xylosus. Chem Eng J 162(1):178-185. doi: 10.1016/j.cej.2010.05. 026.

30. Sarı A, Tuzen M (2010) Biosorption of As (III) and As (V) from aqueous solution by lichen (Xanthoria parietina) biomass. Separ Sci Technol 45(4):463-471. doi:10.1080/01496390903526642, 45 463-471

31. Prasad KS, Srivastava P, Subramanian V, Paul J (2011) Biosorption of As (III) ion on Rhodococcus sp. WB-12: biomass characterization and kinetic studies. Sep Sci Technol 46:2517-2525. doi:10. 1080/01496395.2011.597040, Sep. Sci. Technol. 46 2517-2525

32. Prasad KS, Ramanathan AL, Paul J, Subramanian V, Prasad R (2013) Biosorption of arsenite $\left(\mathrm{As}^{+3}\right)$ and arsenate $\left(\mathrm{As}^{+5}\right)$ from aqueous solution by Arthrobacter sp. biomass. Environ Technol 34(19):2701-2708. doi:10.1080/09593330.2013.786137

33. Sawayama $\mathrm{S}$, Inoue $\mathrm{S}$, Dote $\mathrm{Y}$, Yokoyama $\mathrm{SY}(1995) \mathrm{CO}_{2}$ fixation and oil production through microalga. Energy Convers Mgmr 36(6):729-731. doi:10.1016/0196-8904(95)00108-P

34. Dayananda C, Sarada R, Rani MU, Shamala TR, Ravishankar GA. Autotrophic cultivation of Botryococcus braunii for the production of hydrocarbons and exopolysaccharides in various media. Biomass and Bioenergy 31(1):87-93. doi:10.1016/j.biombioe. 2006.05.001

35. Bundschuh J, Chen G (2014) Sustainable energy solutions in agriculture. In: Bundschuh J, Chen G (Eds.), CRC Press Taylor and Francis Group, London.
36. Kramárová Z, Fargašová A, Molnárová M, Bujdoš M (2012) Arsenic and selenium interactive effect on alga Desmodesmus quadricauda. Ecotoxicol Environ Saf 86:1-6. doi:10.1016/j. ecoenv.2012.08.028

37. Mishra V, Dalal S, Balomajumder C (2013) Optimization of physical parameters for batch mode $\mathrm{Zn}$ (II) ion removal from liquid phase: a potential biosorption study. Environ Progress Sustain Energy 32(2):213-222. doi:10.1002/ep.10637

38. Juneja A, Ceballos RM, Murthy GS. Effects of environmental factors and nutrient availability on the biochemical composition of algae for biofuels production: a review. Energies 6(9):4607-4638. doi: 10.3390/en6094607

39. Sengupta P, Balomajumder C (2014) Potential of corn husk leaves for the co-removal of phenol and cyanide from waste water using simultaneous adsorption and biodegradation. IJRET 3:700-707

40. Shah PD, Galani D, Rao MS (2000) Phycoremediation of industrial wastewater containing azo compounds. NJUET 2(1):1-6

41. Azov Y. Effect of $\mathrm{pH}$ on inorganic carbon uptake in algal cultures. Appl Environ Microbiol 43(6):1300-1306.

42. Nielsen ES (1975) Marine Photosynthesis: With Special Emphasis on the Ecological Aspects, vol 13. Elsevier, Amsterdam, The Netherlands

43. Guckert JB, Cooksey KE (1990) Triglyceride accumulation and fatty acid profile changes in Chlorella (Chlorophyta) during high Ph-induced cell cycle Inhibition ${ }^{1}$. J Phycol 26(1):72-79. doi:10. 1111/j.0022-3646.1990.00072.x

44. Gensemer RW, Smith RE, Duthie HC (1993) Comparative effects of $\mathrm{pH}$ and aluminum on silica-limited growth and nutrient uptake in Asterionella ralfsii var. americana (Bacillariophyceae). J Phycol 29(1):36-44. doi:10.1111/j.1529-8817.1993.tb00277.x

45. E Granum E, Myklestad SM. A photobioreactor with $\mathrm{pH}$ control: demonstration by growth of the marine diatom Skeletonema costatum. J Plankton Res 24(6):557-563. doi: 10.1093/plankt/24.6.557

46. Levy JL, Stauber JL, Adams MS, Maher WA, Kirby JK, Jolley DF (2005) Toxicity, biotransformation, and mode of action of arsenic in two freshwater microalgae (Chlorella sp. and Monoraphidium arcuatum). Environ Toxicol Chem 24(10):2630-2639. doi:10. 1897/04-580R.1

47. Karadjova IB, Slaveykova VI, Tsalev DL (2008) The biouptake and toxicity of arsenic species on the green microalga Chlorella salina in seawater. Aquat Toxicol 87(4):264-271. doi:10.1016/j.aquatox. 2008.02.006

48. Pawlik-Skowrońska B, Pirszel J, Kalinowska R, Skowroński T (2004) Arsenic availability, toxicity and direct role of GSH and phytochelatins in As detoxification in the green alga Stichococcus bacillaris. Aquat Toxicol 70:201-212. doi:10.1016/j.aquatox.2004. 09.003

49. Takimura O, Fuse H, Murakami K, Kamimura K, Yamaoka Y. Uptake and reduction of arsenate by Dunaliella sp. Appl Organomet Chem 10(9):753-756. doi: 10.1002/(SICI)10990739(199611)10:9<753::AID-AOC573>3.0.CO;2-V

50. Dash RR, Balomajumder C, Kumar A (2009) Removal of cyanide from water and wastewater using granular activated carbon. Chem Eng J 146(3):408-413. doi:10.1016/j.cej.2008.06.021

51. Ranjan D, Talat M, Hasan SH (2009) Biosorption of arsenic from aqueous solution using agricultural residue 'rice polish'. J Hazard Mater 166(2):1050-1059. doi:10.1016/j.jhazmat.2008.12.013

52. Pookrod P, Haller KJ, Scamehorn JF (2005) Removal of arsenic anions from water using polyelectrolyte-enhanced ultrafiltration. Sep Sci Technol 39(4):811-831. doi:10.1081/SS-120028448

53. Boddu VM, Abburi K, Talbott JL, Smith ED, Haasch R (2008) Removal of arsenic (III) and arsenic (V) from aqueous medium using chitosan-coated biosorbent. Water Res 42(3):633-642. doi: 10.1016/j.watres.2007.08.014

54. Comte S, Guibaud G, Baudu M (2008) Biosorption properties of extracellular polymeric substances (EPS) towards $\mathrm{Cd}, \mathrm{Cu}$ and $\mathrm{Pb}$ 
for different $\mathrm{pH}$ values. J Hazard Mater 151(1):185-193. doi:10. 1016/j.jhazmat.2007.05.070

55. Chojnacka K, Chojnacki A, Gorecka H. Biosorption of $\mathrm{Cr}^{3+}, \mathrm{Cd}^{2+}$ and $\mathrm{Cu}^{2+}$ ions by blue-green algae Spirulina sp.: kinetics, equilibrium and the mechanism of the process. Chemosphere 59(1):75-84. doi: 10.1016/j.chemosphere.2004.10.005

56. Mashitah MD, Zulfadhly Z, Bhatta S (1999) Binding mechanism of heavy metals biosorption by Pycnoporus sanguineus. J Artif Cells Blood Substit Immobil Biotechnol 27(5-6):441-445. doi:10.3109/ 10731199909117717

57. Hansen HK, Ribeiro A, Mateus E (2006) Biosorption of arsenic (V) with Lessonia nigrescens. Miner Eng 19(5):486-490. doi:10.1016/ j.mineng.2005.08.018

58. Qin J, Lehr CR, Yuan CG, Le XC, Mcdermott TR, Rosen BP (2009) Biotransformation of arsenic by a Yellowstone thermoacidophilic eukaryotic alga. Proc Natl Acad Sci U S A 106:5213-5217. doi:10.1073/pnas.0900238106

59. Zhang SY, Sun GX, Yin XX, Rensing C, Zhu YG (2013) Biomethylation and volatilization of arsenic by the marine microalgae Ostreococcus tauri. Chemosphere 93(1):47-53. doi: 10.1016/j.bbr.2011.03.031

60. Edvantoro BB, Naidu R, Megharaj M, Merrington G, Singleton I (2004) Microbial formation of volatile arsenic in cattle dip site soils contaminated with arsenic and DDT. Appl Soil Ecol 25:207-217. doi:10.1016/j.apsoil.2003.09.006

61. Sanford RA, Klein DA (1988) Environmental bioremediation for organometallic compounds: microbial growth and arsenic volatilization from soil and retorted shale. Appl Organom Chem 2(2):159169. doi:10.1002/aoc.590020210

62. Wang P, Sun G, Jia Y, Meharg AA, Zhu Y (2014) A review on completing arsenic biogeochemical cycle: microbial volatilization of arsines in environment. J Environ Sci 26:371-381. doi:10.1016/ S1001-0742(13)60432-5

63. Abusham RA, Rahman RN, Salleh AB, Basri M (2009) Optimization of physical factors affecting the production of thermo-stable organic solvent-tolerant protease from a newly isolated halo tolerant Bacillus subtilis strain Rand. Microbial Cell Fact 8(1):1-9. doi:10.1186/1475-2859-8-20

64. Shafee N, Aris SN, Rahman RA, Zaliha RN, Basri M, Salleh AB (2005) Optimization of environmental and nutritional conditions for the production of alkaline protease by a newly isolated bacterium Bacillus cereus strain 146. J Appl Sci Res 1(1):1-8

65. Rahman RN, Geok LP, Basri M, Salleh AB (2005) Physical factors affecting the production of organic solvent-tolerant protease by Pseudomonas aeruginosa strain K. Bioresource Technol 96(4): 429-436

66. Jayanthi M, Kanchana D, Saranraj P, Sujitha D (2013) Bioremediation of toxic heavy metal chromium in tannery effluent using bacteria. Appl J Hygiene 2(2):8-14

67. Tempest DW (1978) Dynamics of microbial growth. John Wiley \& Sons, Australia

68. Ray L, Paul S, Bera D, Chattopadhyay P (2005) Bioaccumulation of $\mathrm{Pb}$ (II) from aqueous solutions by Bacillus cereus $\mathrm{M}_{16}^{1}$. J Hazard Subs Res 5(1):1-21

69. Posten C (2009) Design principles of photo-bioreactors for cultivation of microalgae. Eng in Life Sci 9(3):165-177. doi:10.1002/elsc. 200900003

70. Goodwin TW (1980) Nature and distribution of carotenoids. Food Chem 5(1):3-13. doi:10.1016/0308-8146(80)90061-8

71. Prasad (2004) Heavy metal stress in plants: from biomolecules to ecosystems. In: Prasad MNV (Ed) Berlin: Springer-Verlag

72. Bhattacharya P, Pal R (2012) Scope of phycoremediation of Arsenic using Phormidium tenue with special reference to modulation in cellular biochemistry. J Algal Biomass Util 3:1-8

73. Thapar R, Srivastava AK, Bhargava P, Mishra Y, Rai LC (2008) Impact of different abiotic stresses on growth, photosynthetic electron transport chain, nutrient uptake and enzyme activities of Cu-acclimated Anabaena doliolum. J Plant Physiol 165(3):306316. doi:10.1016/j.jplph.2007.05.002, (165) 306-316

74. Shakya K, Chettri MK, Sawidis T. Impact of heavy metals (copper, zinc, and lead) on the chlorophyll content of some mosses. Arch Environ Contam Toxicol 54(3):412-21. doi: 10.1007/s00244-0079060-y

75. Mishra V, Balomajumder C, Agarwal VK (2010) Zn (II) ion biosorption onto surface of eucalyptus leaf biomass: isotherm, kinetic, and mechanistic modeling. CLEAN-Soil, Air, Water 38(11): 1062-1073. doi:10.1002/clen.201000030

76. $\mathrm{Hu} \mathrm{Q}$ (2004) Environmental effects on cell composition. In: Richmond A (ed) Handbook of microalgal culture: biotechnology and applied phycology. Blackwell, Oxford, UK, pp 83-93

77. Larned ST (1998) Nitrogen-versus phosphorus-limited growth and sources of nutrients for coral reef macroalgae. Mar Biol 132(3): 409-421. doi:10.1007/s002270050407

78. Borchardt JA, Azad HS (1968) Biological extraction of nutrients. J Water Pollut Control Fed 40:1739-1754

79. Chisti Y (2013) Constraints to commercialization of algal fuels. J Biotechnol 167(3):201-214. doi:10.1016/j.jbiotec.2013.07.020

80. Kobayashi M, Kakizono T, Nagai S (1993) Enhanced carotenoid biosynthesis by oxidative stress in acetate-induced cyst cells of a green unicellular alga, Haematococcus pluvialis. Appl Environ Microbiol 59(3):867-873

81. Wang NX, Li Y, Deng XH, Miao AJ, Ji R, Yang LY. Toxicity and bioaccumulation kinetics of arsenate in two freshwater green algae under different phosphate regimes. Water Res 47(7):2497-2506. doi: 10.1016/j.watres.2013.02.034

82. Knauer K, Hemond $\mathrm{H}$. Accumulation and reduction of arsenate by the freshwater green alga Chlorella sp. (Chlorophyta). J Phycol 36(3):506-509. doi: 10.1046/j.1529-8817.2000.99056.x.

83. Sanders JG (1979) Effects of arsenic speciation and phosphate concentration of arsenic inhibition of Skeletonema costatum

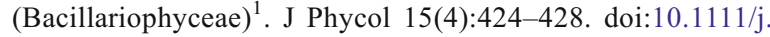
1529-8817.1979.tb00714.x

84. Foster S, Thomson D, Maher W. Uptake and metabolism of arsenate by anexic cultures of the microalgae Dunaliella tertiolecta and Phaeodactylum tricornutum. Mar Chem 108(3):172-183. doi: 10. 1016/j.jhazmat.2011.01.092

85. Awual MR, Jyo A, El-Safty SA, Tamada M, Seko N (2011) A weak-base fibrous anion exchanger effective for rapid phosphate removal from water. J Hazard Mater 188(1):164-171. doi:10.1016/ j.marchem.2007.11.005

86. Schwendtner K, Kolitsch U. Alkali scandium arsenates. II. The framework structures of $\alpha$ - and $\beta-\mathrm{CsSc}\left(\mathrm{HAsO}_{4}\right)_{2}$. Acta Crystallogr C 60(9):i84-i88. doi: 10.1107/S010827010401594X

87. Troup JM, Clearfield A (1977) On the mechanism of ion exchange in zirconium phosphates. 20. Refinement of the crystal structure of $\alpha$-zirconium phosphate. Inorg Chem 16:3311-3314. doi:10.1021/ ic50178a065

88. Feng P, Zhang T, Bu X (2001) Arsenate zeolite analogues with 11 topological types. J Am Chem Soc 123(35):8608-8609. doi:10. 1021/ja0114658

89. Thakkar R, Chudasama U (2009) Synthesis, characterization and proton transport property of crystalline-zirconium titanium phosphate, a tetravalent bimetallic acid salt. J Sci Ind Res 68(4):312-318

90. Awual MR, Jyo A (2011) Assessing of phosphorus removal by polymeric anion exchangers. Desalination 281:111-117. doi:10. 1016/j.desal.2011.07.047

91. Balaji T, Yokoyama T, Matsunaga H (2005) Adsorption and removal of As (V) and As (III) using Zr-loaded lysine diacetic acid chelating resin. Chemosphere 59(8):1169-1174. doi:10.1016/j. chemosphere.2004.12.007 
92. Dayananda C, Kumudha A, Sarada R, Ravishankar GA (2010) Isolation, characterization and outdoor cultivation of green microalgae Botryococcus sp. Sci Res Essays 5(17):2497-2505

93. Malkoc E, Nuhoglu Y, Dundar M (2006) Adsorption of chromium (VI) on pomace - an olive oil industry waste: batch and column studies. J Hazard Mater 138(1):142-151. doi:10.1016/j.jhazmat. 2006.05.051

94. Singha B, Das SK (2011) Biosorption of Cr (VI) ions from aqueous solutions: kinetics, equilibrium, thermodynamics and desorption studies. Colloids Surf B 84(1):221-232. doi:10.1016/j.colsurfb. 2011.01.004

95. François F, Lombard C, Guigner JM, Soreau P, Brian-Jaisson F, Martino G, Vandervennet M, Garcia D, Molinier AL, Pignol D, Peduzzi J (2012) Isolation and characterization of environmental bacteria capable of extracellular biosorption of mercury. Appl Environ Microbiol 78(4):1097-1106. doi: 10.1128/AEM.06522-11
96. Baig JA, Kazi TG, Shah AQ, Kandhro GA, Afridi HI, Khan S, Kolachi NF (2010) Biosorption studies on powder of stem of Acacia nilotica: removal of arsenic from surface water. J Hazard Mater 178(1):941-948. doi:10.1016/j.jhazmat.2010.02.028

97. Pokhrel D, Viraraghavan T (2007) Arsenic removal from an aqueous solution by modified $A$. niger biomass: batch kinetic and isotherm studies. J Hazard Mater 150:818-825. doi:10.1016/j.jhazmat. 2007.05.041, J Hazard Mater 150 818-825

98. Mondal P, Balomajumder C, Mohanty B. A laboratory study for the treatment of arsenic, iron, and manganese bearing ground water using $\mathrm{Fe}^{3+}$ impregnated activated carbon: effects of shaking time, $\mathrm{pH}$ and temperature. J Hazard Mater 144(1):420-426. doi: 10.1016/ j.jhazmat.2006.10.078

99. Li Z, Deng S, Yu G, Huang J, Lim VC (2010) As (V) and As (III) removal from water by a $\mathrm{Ce}-\mathrm{Ti}$ oxide adsorbent: behavior and mechanism. Chem Eng J 161(1):106-113. doi:10.1016/j.cej.2010.04.039 